Article

\title{
Exploring Biogas and Biofertilizer Production from Abattoir Wastes in Nigeria Using a Multi-Criteria Assessment Approach
}

\author{
Idi Guga Audu ${ }^{1,2, *}$, Abraham Barde ${ }^{3}\left(\mathbb{D}\right.$, Othniel Mintang Yila ${ }^{4}$, Peter Azikiwe Onwualu ${ }^{5}$ and \\ Buga Mohammed Lawal ${ }^{1}$ \\ 1 Raw Materials Research and Development Council, 17 Aguiyi Ironsi St, Maitama District, \\ Abuja 900211, Nigeria; mblawal@hotmail.com \\ 2 Department of Food Engineeering, Technical University Dresden, Bergstraße 120, 01069 Dresden, Germany \\ 3 Armament Engineering Department, Air Force Institute of Technology, Kaduna 800282, Nigeria; \\ abraham-barde@nda.edu.ng \\ 4 Ministry of Meteorology, Energy, Information, Disaster Management, Environment, Climate Change \\ and Communications (MEIDECC), Nuku'alofa 00100, Tonga; othnielyila@gmail.com \\ 5 Materials Science and Engineering Programme, African University of Science and Technology, \\ Abuja 900211, Nigeria; aonwualu@aust.edu.ng \\ * Correspondence: idig.audu@gmail.com
}

Received: 2 June 2019; Accepted: 12 August 2020; Published: 19 August 2020

\begin{abstract}
Management of waste streams from abattoirs is a major challenge in developing countries. Harnessing these wastes as resources for the production of biogas and biofertilizer could contribute to curbing the environmental menace and to addressing the problems of energy and food deficits in Nigeria. However, large scale uptake of the technology is faced with techno-socio-economic and the lack of data required for effective investment decisions. In this study, the potential use of waste generated in the north central region of Nigerian abattoirs, representing approximately $12 \%$ of the land and $6 \%$ of the population, were evaluated for suitability for biogas and biofertilizer production. Data acquired from the study sites were used for computational estimation and integrated into strengths, weaknesses, opportunities, and threats (SWOT) analysis to give a detailed overview of the prospects and the limiting factors. The study revealed that high investment costs and public subsidies for fossil fuels are the key limiting factors while the prospects of tapping into the unexploited carbon markets and multiple socio-economic and environmental benefits favors investment. Public supports in the form of national policy reforms leading to intervention programs are required for progress.
\end{abstract}

Keywords: abattoir wastes; biogas; biofertilizer; anaerobic digestion; environmental pollution

\section{Introduction}

Due to increasing population and standards of living, energy production in Nigeria and $\mathrm{CO}_{2}$ emission increased from 146.3 million tons of oil equivalent (Mtoe) and $28.06 \mathrm{Mt}$ of $\mathrm{CO}_{2}$ in 1990 to 239.77 Mtoe and 85.09 Mt of $\mathrm{CO}_{2}$ in 2016 respectively [1], Figure 1. The greatest part of the primary energy mix is from biomass and wastes contributing $82.2 \%$ while oil, natural gas and hydropower contributes meager values of $10.6 \%, 6.8 \%$ and $0.4 \%$ respectively [2]. On the other hand, land use and forestry contributed the most $\mathrm{CO}_{2}$ emission (38.2\%) followed by energy (32.6\%) with wastes, agriculture and industrial processes contributing $14 \%, 13 \%$ and $2.1 \%$ respectively [3]. Like other African countries, where only about $36 \%$ of the population has access to electricity [4], electricity deficit is a challenge in Nigeria. Although the total installed capacity for electricity generation from power plants is 12,067 MW, actual generation was only $3941 \mathrm{MW}$ in 2015 [3]. Some of the challenges facing the 
electricity supply sector that leads to this under-delivery include shortage of gas, poor maintenance, inadequate regulations or inability to enforce them and vandalization of energy infrastructure [3]. In the absence of electricity and high cost of fossil fuels like cooking gas (LNG) and kerosene, most people turn to wood fuel and agricultural residues as energy sources for cooking. Additionally, the level of food insecurity in Nigeria has steadily increased since the 1980s, rising from $18 \%$ in 1986 to about $41 \%$ in 2004 [5]. Sub-optimal supply of agricultural inputs, especially fertilizers, is one of the key challenges leading to persisting food insecurity [6]. Unfortunately, the current major source of fertilizers in Nigeria is fossil based. Application of synthetic fertilizers contributes significantly to greenhouse gas (GHG) emissions [7,8]. Wastes from abattoirs contribute significantly to possible foodborne disease hazards and have adverse effects on air quality, agriculture, potable water, and aquatic life [9]. Uncontrolled disposal of the wastes results in methane $\left(\mathrm{CH}_{4}\right)$ emissions from the manure, untreated organic wastes and wastewater. The current waste disposal practices in most abattoirs in Nigeria is to dump rumen content and other solid wastes at nearby designated sites while the liquid phase resulting from washings are allowed to flow into the drains [9-12]. However, animal by-products from slaughterhouses could be processed by anaerobic digestion (AD) to simultaneously produce methane for energy and nutrient rich effluent as biofertilizer [13], which may be a way of curbing the menace of such wastes in many cities in Nigeria [14]. Biogas and biofertilizer production from abattoir waste streams could contribute to lowering fossil fuel and inorganic fertilizer applications. This will also provide an efficient waste recycling method, thereby lowering GHG emissions from open manure storage [15]. Biogas is a valuable source of energy with varying applications such as electricity generation, lighting, cooking, and transportation [16]. The spent substrate is a very useful biofertilizer and can be used to offset the financial as well as the environmental costs associated with the use of mineral fertilizers $[15,16]$. Sustainable and efficient biogas and biofertilizer production from such waste recycling is a promising method towards attaining a circular economy. These facts support the need to invest in efficient recycling method like $\mathrm{AD}$, to process wastes streams generated in abattoirs as a means to curb the environmental hazards as well as provide valuable materials from renewable resources to contribute in meeting energy and food needs.

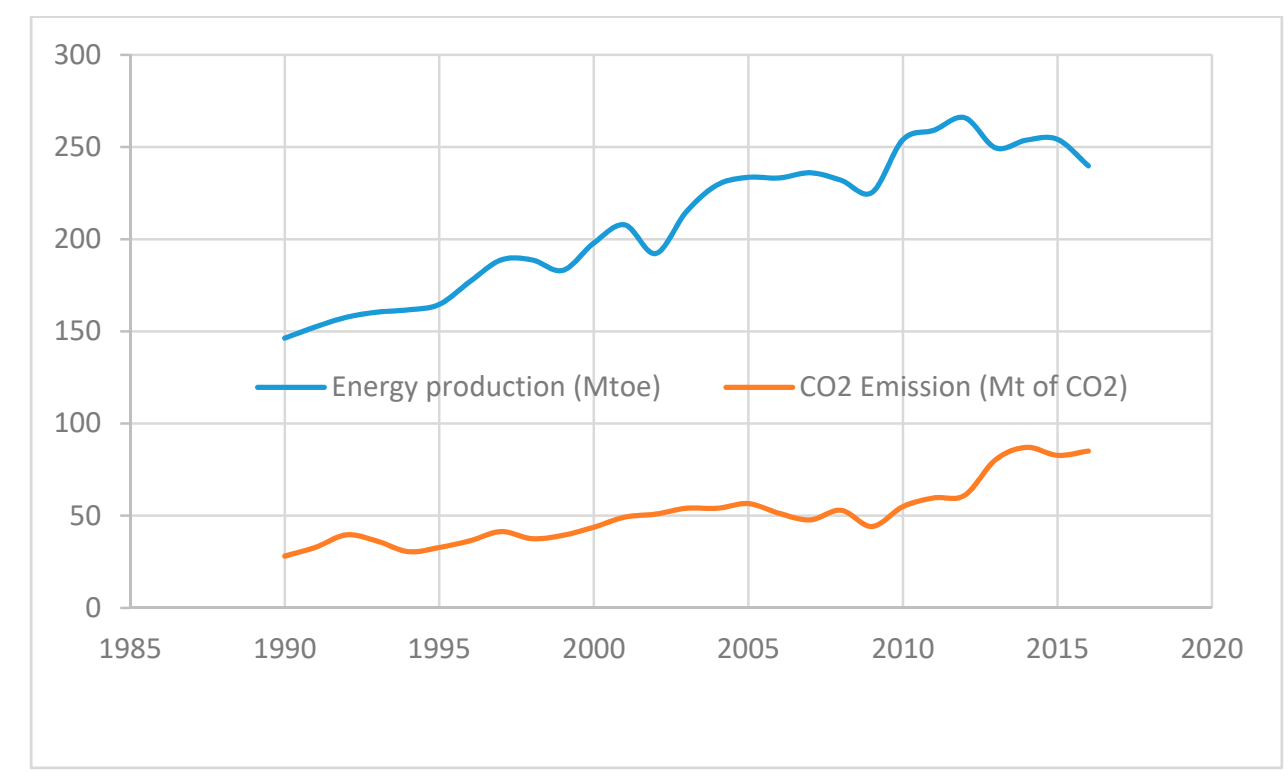

Figure 1. Energy production and $\mathrm{CO}_{2}$ emissions between 1990 to 2016 in Nigeria (source: [1]).

Several experiments have demonstrated success in converting abattoir wastes by AD into biogas and biofertilizer $[17,18]$, as well as its potency in reducing environmental pollution problems associated with abattoir waste disposal. The GHG emission reduction potential could be determined using 
mathematical computation given by the Intergovernmental Panel on Climate Change (IPCC) [19], Joint Global Change Research Institute (JGCRI) [20], and Tolera and Alemu [21]. The AD process could also be improved by applying enzymes to produce animal feed from fibrous agricultural wastes like sugarcane bagasse and wheat straw for improved bio-utilization of nutrient contents and the biodegradation of fibrous feeds [22]. In a study by Klintenberg et al. [23] in Namibia, an AD process using a combination of manure, blood, and stomach contents similar to the proportions in abattoir waste generated the highest biogas cumulative output compared to other sampled combinations. Ware and Power [24] demonstrated in Ireland that mixed waste streams from cattle slaughterhouses, consisting of $28.4 \%, 41.0 \%$, and $27.3 \%$ fats, carbohydrates, and proteins, respectively are viable for producing high levels of $\mathrm{CH}_{4}$. Other studies in Nigeria revealed that abattoir substrates have a low concentration of toxic substances, which would inhibit the process, ultimately resulting in high $\mathrm{CH}_{4}$ output, suggesting that the substrates are suitable for biogas production $[25,26]$.

The idea of converting abattoir wastes to produce biogas and biofertilizer has long been pursued and is increasingly relevant in sustainability. For example, TekniskaVerken in Linkoping, Sweden has long term experience in handling large volume of slaughterhouse wastes for biogas production [27]. Through sustained efforts on research and development by this company, several improvements have been recorded including better odor control, higher organic wastes loading rate, higher biogas quality and yields [27]. Svensk Biogas AB (SvB) operates a co-digestion plant for slaughterhouse waste for biogas production in which the input from slaughterhouse waste ranges from $35 \%$ to $75 \%$ [27]. The plant which began in 1996 increased from annual capacity of 55,000 tons to 100,000 tons in 2010. Underpinning the success of this company is the continuing research on biogas production by the company in association with Linkoping University and the Swedish University of Agricultural Science [28]. Despite the several benefits and demonstrated experiences for biogas and biofertilizer production from abattoir wastes, large-scale development of the technology in Nigeria is still at a nascent stage [29]. The reasons for the present lack of uptake of this technology have not been analyzed, and therefore, require investigation. The question around using "slaughterhouse waste for biogas and biofertilizer production" is a multi-dimensional one and requires a methodology that allows systematic investigation of such multi-dimensional issues. The issues include questions regarding the local situation on energy access, resource depletion, climate change mitigation, feedstock availability and terms of accessibility, current use of feedstock that may compete with the proposed biogas plant and space to accommodate biogas plant in close proximity to the source of wastes. Further to these, is the economic demand side for the products (fertilizer and electricity) All these need to be investigated. In addition, socio-economic and environmental considerations are critical in understanding the barriers against uptake of the technology. Thus, the research questions this study attempts to address are:

i. What is the potential for biogas and biofertilizer production using abattoir wastes in Nigeria?

ii. What are the socio-economic and environmental merits and demerits of adopting this technology?

iii. Why the very low level of the development and adoption of the technology in Nigeria?

Consequently, the objective of this study was, therefore, to evaluate the possibility of biogas and biofertilizer production from waste streams in Nigerian abattoirs. The adoption of this technology could be limited by economic, environmental, social, and ethical constraints. Due to complexities in implementing biogas projects, wide range of factors related to biogas system analysis, site-specific properties and the local community situations must be considered to provide workable information for decision-making in specific localities. Suitable tools are required to ensure a well-thoughtout analysis of the factors that affect biogas systems, to ensure informed decision-making. Several tools have been used for such analyses. For instance, the Political, Economic, Social, Technological, Legal and Environmental (PESTLE); the Technique for Order of Preference by Similarity to Ideal Situations (TOPSIS); the Analytic Hierarchy Process (AHP); and the Strengths, Weaknesses, Opportunities and Threats (SWOT). Among these, SWOT has the advantage of combining some elements of the other 
methods, making it more comprehensive. Therefore, in this study, strengths, weaknesses, opportunities, and threats (SWOT) analysis was selected as the tool for initial assessment of the techno-socio-economic benefits and risks of biogas production from abattoirs in Nigeria. The analysis is targeted at identifying internal strengths and weaknesses as well as the external opportunities and threats that can endanger biogas production from abattoirs in the selected case study in Nigeria. To avoid the limitations of SWOT, which only provides qualitative descriptions [30,31], we incorporated tangible and measurable data from the selected case study sites to provide a comprehensive view of the possibility of biogas and biofertilizer production from abattoirs in Nigeria. The case study sites were the abattoirs in the Federal Capital Territory (FCT)-Abuja, and Niger and Nassarawa States.

\section{Materials and Methods}

\subsection{Study Location, Data Collection Method and Quantifications}

Description of study sites: The study sites were in the north central region of Nigeria. The selected sites included Karu abattoir in the FCT-Abuja, Minna and Suleja abattoirs in Niger State, and Lafia abattoir in Nassarawa State (Figure 2). The total land area of the study location is $110,795 \mathrm{~km}^{2}$, which represents $12 \%$ of Nigeria's land area. The population in 2015, projected from the 2006 census, was 11 million, thus representing $6 \%$ of Nigeria's population. The region produces livestock (cattle, sheep, and goats), and is among the leading Nigerian producers of some crops such as cassava, rice, yam, melon, plantain, and banana.

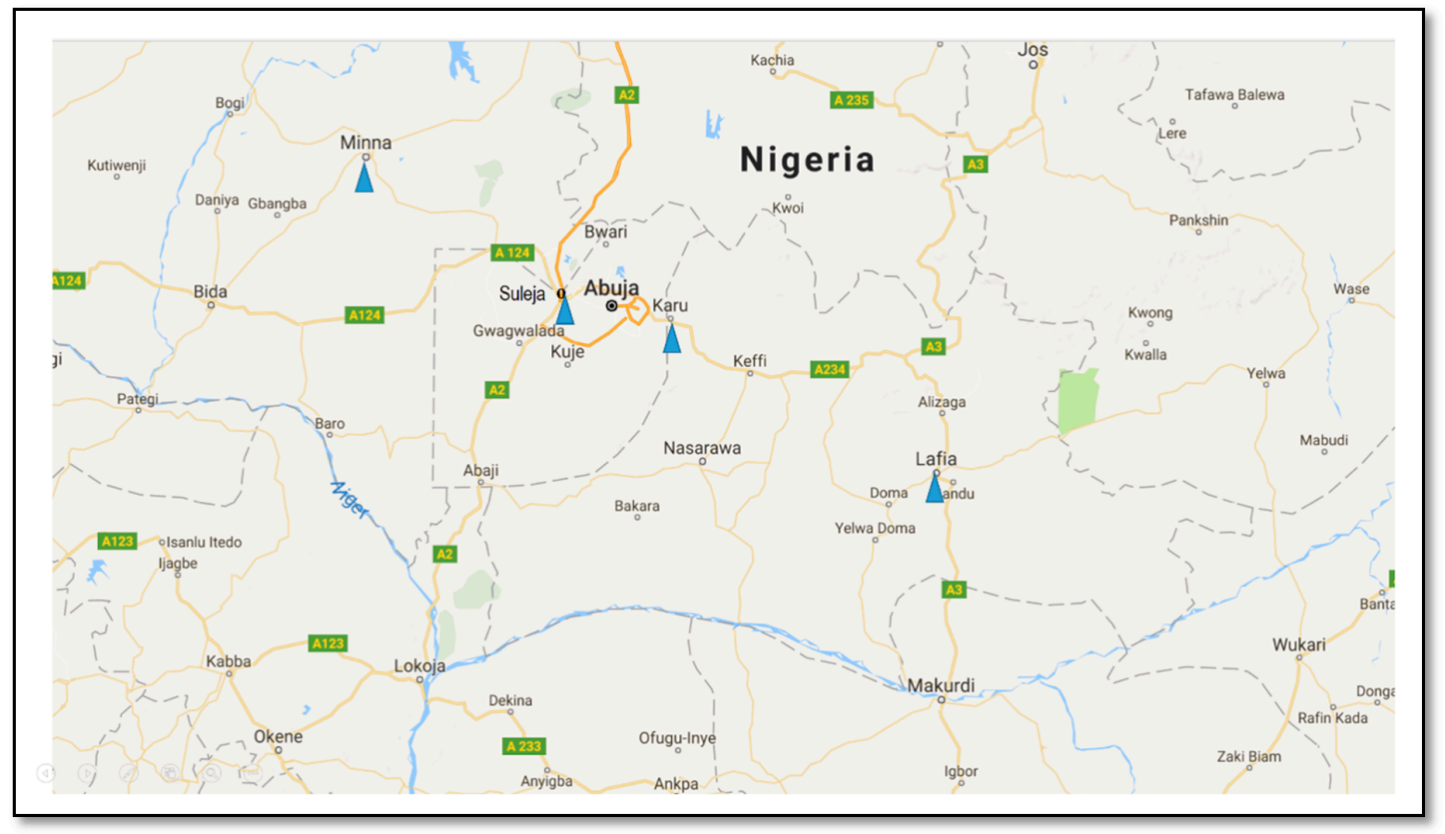

Figure 2. Map of the study region showing the location of the sites (blue rectangle). Source-Google maps.

Data collection/collation approach: We initially developed and distributed a questionnaire to identify the types and number of animals slaughtered per day. We then visited each study site to gain information on their production and administration. In addition, the local situation such as current energy sources, current use of the wastes, available facilities for waste disposal, waste disposal methods and effects on the environment were assessed for each study site. The volume of wastes generated and, hence, other parameters were calculated from the data of the number of animal slaughter acquired from the survey. Generally, the mathematical computations used in this study were in accordance with acceptable standard coefficients and measurements. 
Feedstock generation potential/estimation methods: Based on the primary data of the average daily slaughters acquired from the respective study sites, the annual slaughters, total wastes and potentials were determined. For estimating the quantity of waste from abattoir which could be utilized for $\mathrm{AD}$, a coefficient of $35 \%$ of the body weight of the animal slaughtered has been used by the World Bank 1998 and Akinbomi et al. 2014 [32]. The waste generated by each animal was therefore taken as $35 \%$ of its body weight; for cattle, the average body mass used was $353 \mathrm{~kg}$, while the corresponding numbers for sheep and goat were 33 and $23 \mathrm{~kg}$, respectively [32]. Waren and Power (2016) used $193.37 \mathrm{~kg} /$ head of cattle [24], a value higher than $35 \%$ of $353 \mathrm{~kg}$ used for cattle in this study. The value $35 \%$ of the body weight was deliberately used in this study to avoid overestimation. In this study, the data obtained for sheep and goats were combined values, as the number of sheep and goats were not segregated, therefore, an average of $28 \mathrm{~kg}$ was used in the estimates for sheep and goats.

Biogas Production Potential and Energy Potential Estimation Methods: Some coefficients used in estimating biogas and electricity generation potential include: dry matter (DM) which was taken as $15 \%$ of total wastes [33], volatile solid (VS) as $96.7 \%$ of DM [24], and the biomethane potential (BMP) was $700 \mathrm{~m}^{3} / \mathrm{t}$ VS [34]. Provision was made for downtime, to cover the possibilities for maintenance, unforeseen stoppages, and incubation time before biogas generation began. Based on this, $75 \%$ of the BMP was applied to obtain the overall electricity potential. The electricity potential was based on $3.73 \mathrm{kWh} / \mathrm{m}^{3} \mathrm{CH}_{4}$ [32], using the adjusted BMP.

Bio-Fertilizers Yield Potential Estimation Method: For the biofertilizer potential, only about $60 \%$ VS is converted to biogas [35]. Similarly, VS reductions to a range of $40 \%$ to $46 \%$ after about 80 days of AD of some organic substrates were observed by Schirmer et al. [36]. We therefore applied $40 \%$ of VS as the dry matter remaining after the AD process. Thus, potential biofertilizer yield (dry) was by Equation (1) [29].

$$
\operatorname{PBF}(\text { dry })=(\mathrm{DM}-\mathrm{VS})+(40 \% \mathrm{VS})
$$

where: $\mathrm{DM}=$ dry mass, $\mathrm{VS}=$ volatile solids, i.e., portion of DM that is potentially converted to biogas.

The optimal total solid of the digester was $15 \%$ which was used to estimate the bulk density by applying Equation (2), proposed by Chen [37], from which the volume of the slurry was obtained.

$$
\varrho=998 /(1-0.00345 \mathrm{TS})
$$

where: $\varrho=$ bulk density $\left(\mathrm{kg} / \mathrm{m}^{3}\right)$, TS $=$ total solids $(\%)$; TS ranges from $0-16 \%$. Taking TS $=15 \%, \varrho=$ $1052 \mathrm{~kg} / \mathrm{m}^{3}$ was obtained and applied.

Estimation of Possible Reduction of Green House Gas (GHG) Emissions: The decrease in GHGs by the production of biogas from abattoir waste was calculated using the mathematical computational method developed by IPCC and applied by Tolera and Alemu [21], expressed as GHG reduction potential of $\mathrm{AD}$ equal to the estimate of GHG emissions from dumping sites minus the estimate of GHG emissions from AD:

$$
\text { GHG Emission }=\lfloor((Q \times D O C \times D O C F \times F 1 \times 1.336)-R) \times(1-O X) \times 25\rfloor
$$

Estimation of cutback of GHGs using AD for biogas production:

$$
G H G r=\lfloor((Q \times D O C \times D O C F \times F 1 \times 1.336)-R) \times(1-O X) \times 25\rfloor-\sum(Q j \times E F j)
$$

whereby $([(Q \times D O C \times D O C F \times F 1 \times 1.336)-R] \times(1-O X) \times 25)$ is the $G H G$ emission potential of the dumping sites and $\sum(Q j \times E F j)$ is the GHG emission potential of the abattoir waste AD production plants for biogas factoring in the $\mathrm{CH}_{4}$ global warming potential used to convert the quantity of methane emitted to the carbon (iv) oxide in equivalence $\left(\mathrm{CO}_{2} \mathrm{eq}\right)$ from the quantity of abattoir waste produced. 
The variables are defined as follows:

$Q=$ the quantity of slaughterhouse waste from waste records $(\mathrm{t} / \mathrm{kg})$;

$D O C=$ the degradable organic carbon expressed as a proportion of abattoir waste with default value $(\mathrm{DV})=0.12$;

$D O C F=$ the fraction of degradable organic carbon dissimilated for the abattoir waste whose DV $=0.7$; $F 1=$ the fraction of methane produced from dumping sites, $\mathrm{DV}=0.50$;

The value 1.336 is the rate that carbon is being converted to methane;

$R=$ annual recovery of methane, quantified in tons (here no recovered methane);

$O X=$ the oxidation factor, $\mathrm{DV}=0.1$ for well-managed and $\mathrm{DV}=0$ for unmanaged);

The value 25 is the $\mathrm{CH}_{4}$ global warming potential;

$Q j=$ the amount of the given type of waste $\mathrm{j}$ (here is only abattoir waste);

$E F j=$ the biogas emission factor of the given waste type $\mathrm{j}, \mathrm{DV}=0.02 \mathrm{~kg} \mathrm{CO}_{2}$ eq.

Estimation of Biogas Equivalence of Fossil Fuels: Amigun and Blottnitz [18] and B-Sustain's [38] provided a comparative energy value estimation which showed that $1 \mathrm{~m}^{3}$ of biogas is equivalent to coefficient factor of $0.45 \mathrm{~kg}$ liquefied petroleum gas (LPG), $0.6 \mathrm{~kg}$ kerosene (K), $0.4 \mathrm{~kg}$ furnace oil (FO), $0.7 \mathrm{~kg}$ petrol (P), $0.5 \mathrm{~kg}$ diesel (D), or $3.50 \mathrm{~kg}$ firewood(FW) in the same activities.

Biogas Equivalent of a given

$$
\text { Fossil Fuel }=\sum \mathrm{CFF} \times \mathrm{BV}
$$

where CFF is coefficient factor of any fuel as given above; BV is the biogas volume produced.

\subsection{SWOT Analysis}

Due to complexities in implementing biogas projects, various assessment methodologies have been applied [39]. In view of the wide range of factors related to biogas system analysis, site-specific properties and the local community situations must be considered to provide workable information for decision-making in specific localities. Suitable tools are required to ensure a thorough analysis of the factors that affect biogas systems for informed decision-making. Several tools have been used for such analyses. For instance, the Political, Economic, Social, Technological, Legal and Environmental (PESTLE) tool is widely used to analyze the prospects and potential risks and screen the external marketing environment of an investment or a company [40]; the Technique for Order of Preference by Similarity to Ideal Situations (TOPSIS) grades the alternatives with respect to their geometric distance from the positive and negative ideal solutions [41]; the Analytic Hierarchy Process (AHP) applies mathematics and psychology to organize and analyze complex decisions [42]; and the Strengths, Weaknesses, Opportunities and Threats (SWOT) is a tool for auditing a system and its internal and external environment by building on the strengths and opportunities, correcting the weaknesses and protecting the threats [43]. Among these, SWOT seems to be the most popular, with its advantage of combining some elements of the other methods. For example, several aspects of PESTLE are well captured in SWOT. SWOT is a strategic planning tool, which originated from business management, and is applied to detect and assess the strengths $(\mathrm{S})$, weaknesses $(\mathrm{W})$, opportunities $(\mathrm{O})$ and threats $(\mathrm{T})$ of a project or product that is being evaluated. The structure of the SWOT matrix (Figure 3) defines the strengths and weaknesses of the assessed system as internal characteristics, while the opportunities and threats are external factors that influence the success or failure of the system [44]. 


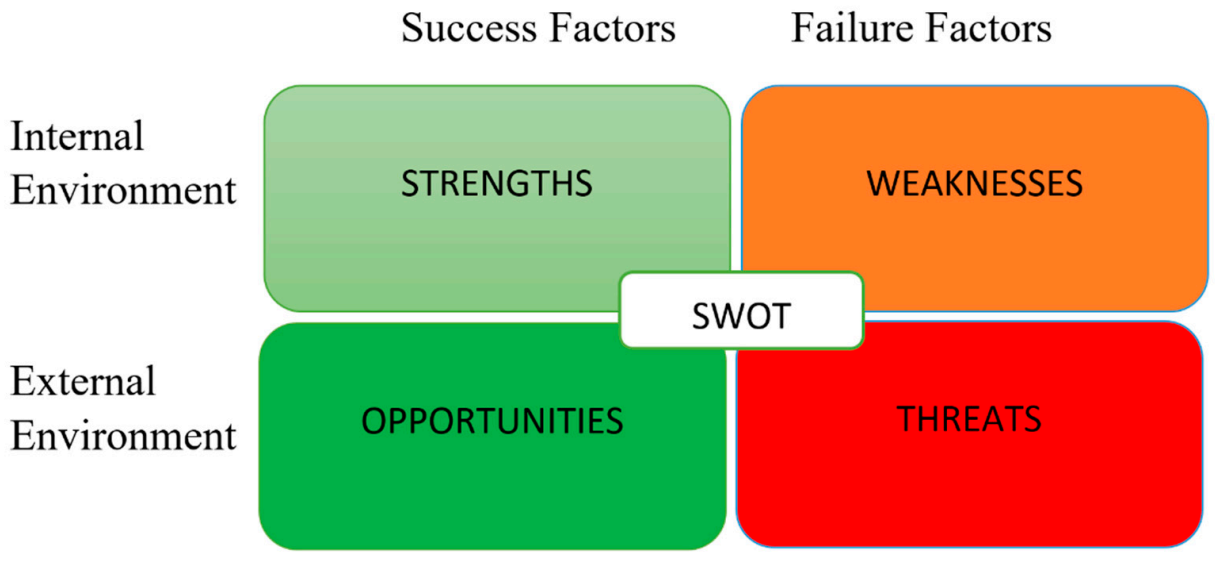

Figure 3. SWOT matrix structure: [44].

\subsection{SWOT Matrix Development and Identification of Factors}

Based on the SWOT matrix framework in Figure 3 and results of the initial site surveys, the various SWOT factors were identified (Table 1). The steps were as follows:

- Identification of all internal aspects of biogas and biofertilizer production from the abattoirs, which might influence the project, followed by classification of favorable factors as strengths and unfavorable ones as weaknesses.

- Identification of external factors that may influence the project, looking at the global and local scenarios in Nigeria, and classifying the negative factors as threats and the positive ones as opportunities.

Table 1. Identified SWOT factors for biogas and biofertilizer production using abattoir wastes in Nigeria.

\begin{tabular}{|c|c|c|}
\hline & Positive & Negative \\
\hline $\begin{array}{c}\text { Internal } \\
\text { Environment }\end{array}$ & $\begin{array}{l}\text { Strengths } \\
\text { - } \quad \text { Feedstock availability } \\
\text { - } \quad \text { Suitable climate } \\
\text { Provision of clean energy and } \\
\text { biofertilizer alternative } \\
\text { - } \quad \text { Kills pathogenic organisms } \\
\text { - } \quad \text { Solves waste disposal problems } \\
\text { Reduction of GHG emission and } \\
\text { - } \quad \text { Exeful for closing carbon cycle } \\
\text { - } \quad \text { Flexibility for small, medium and } \\
\quad \text { large plant }\end{array}$ & $\begin{array}{l}\text { Weaknesses } \\
\text { - } \quad \text { High investment cost } \\
\text { - } \quad \text { Lack of continuity in developing } \\
\text { technical proficiency } \\
\text { Relative novelty, adoption may } \\
\text { face resistance, } \\
\text { sensitization needed } \\
\text { - } \quad \text { Lack of access to water } \\
\text { - } \quad \text { Pagh protein in abattoir wastes } \\
\text { - } \quad \text { Oventaminated materials } \\
\text { biogas system }\end{array}$ \\
\hline $\begin{array}{c}\text { External } \\
\text { Environment }\end{array}$ & $\begin{array}{l}\text { Opportunities } \\
\text { - } \quad \text { Energy deficits and rural settings, } \\
\text { favors decentralization } \\
\text { - } \quad \begin{array}{l}\text { Food insecurity and calls for } \\
\text { diversifying Nigeria's economy }\end{array} \\
\text { - } \quad \text { Improved public health } \\
\text { - } \quad \text { Job opportunities } \\
\text { - } \quad \text { Increased economic activities } \\
\text { - } \quad \text { Synergizes global goals of } \\
\text { - } \quad \text { Publimate mitigation }\end{array}$ & $\begin{array}{l}\text { Threats } \\
\text { - Competitive product } \\
\text { undercuts prices } \\
\text { - } \quad \text { Low level of understanding of } \\
\text { environmental problems } \\
\text { among citizens } \\
\text { - Too expensive and high } \\
\text { lending rate } \\
\text { - Public subsidies for fossil-based } \\
\text { energy and fertilizer }\end{array}$ \\
\hline
\end{tabular}




\section{Results}

\subsection{State of the Abattoirs Assessed-Quantitative and Qualitative Assessment}

A total of four abattoirs, namely, Minna, Suleja, Karu, and Lafia, were evaluated. Based on the survey, Table 2 shows the raw data of daily slaughter and types of animal slaughtered from which annual feedstock values were calculated and further analyses were conducted to obtain the electricity and biofertilizer potentials. Animals slaughtered included cattle, sheep, and goats. However, at Minna abattoir, occasionally, a few camels were also slaughtered. Suleja had the highest number of cattle slaughtered followed by Karu, while Karu had the highest number of sheep and goats slaughtered followed by Minna.

Table 2. Average daily number of animal slaughters from the study sites.

\begin{tabular}{ccccc}
\hline Abattoir Assessed & Suleja & Minna & Lafia & Karu \\
\hline Location/State & Niger & Niger & Nassarawa & FCT \\
Slaughter (Cattle) & 180 & 60 & 45 & 135 \\
Slaughter (Sheep and Goats) & 19 & 95 & 61 & 650 \\
\hline
\end{tabular}

In each abattoir, there was an animal holding area to keep a few animals for some time, either to fatten them before they were slaughtered or to house them when the number of available animals exceeded the number slated for slaughter for the day. Therefore, some animal dung was generated in the animal holding area during the night. Additionally, fruit and vegetable markets adjoin the abattoirs at Suleja and Karu, and a cattle market is located near the Lafia abattoir. On the other hand, the Minna abattoir is strictly isolated for abattoir operations. Thus, besides the wastes generated in the abattoirs, additional wastes were obtainable from fruit and vegetable markets and the animal holding areas near the abattoirs.

None of the abattoirs had automated systems for meat and waste processing. The rumen contents were conveyed using wheelbarrows to the designated dumping sites (Figure 4). There were obvious stinking smells in the areas. Two of the rumen dump sites were close to streams near the Karu and Suleja abattoirs. These show a more pronounced danger of surface water pollution, resulting in possible public health and environmental hazards, especially to the users of water residing downstream.

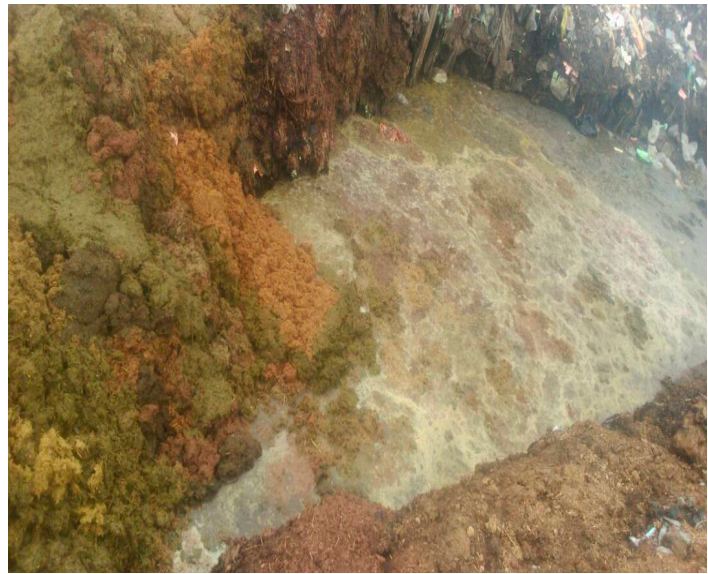

(a)

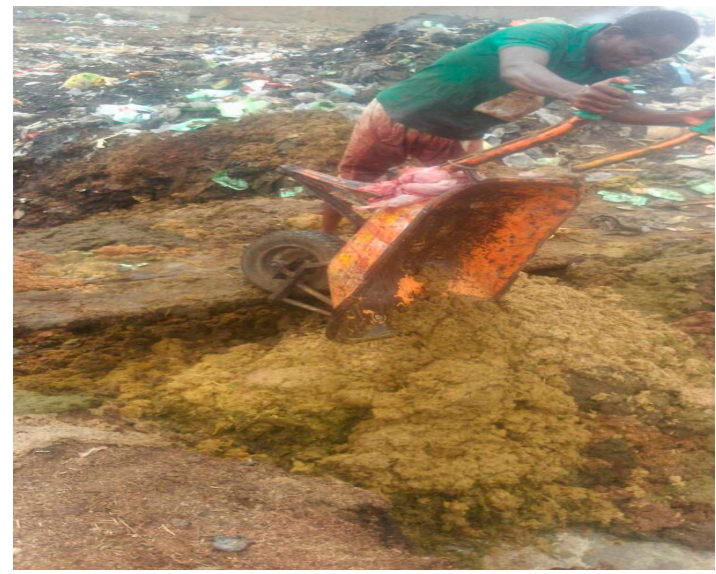

(b)

Figure 4. Waste from Suleja abattoir dumped at a nearby stream. (a) Waste dumped at nearby stream; (b) Dumping of waste.

In all the study sites, wastes streams are currently not put into use, the wastes could therefore be made available for AD plants following appropriate discussions and agreements. The authorities 
concerned in supervising the activities of the abattoirs in all the sites expressed similar interest on the idea of AD plant as means for wastes management and efficient resource utilization. While the abattoirs in Minna, Suleja and Lafia have abundant land area that could accommodate AD plants near the slaughterhouses, Karu abattoir has limited land area for this project in the current site. The current energy source for cooking in the communities in the study sites is not any different to most part of Nigeria. These are fossil fuel and more often wood fuel that is hauled without replenishing, thereby leading to deforestation, erosion and degradation of soil quality.

\subsection{Estimate of Waste Generated, Biomethane, Electricity, Biofertilizer and Methane Emission Mitigation Potentials}

The raw data obtained from each abattoir were used to estimate the biogas, electricity, and biofertilizer potentials, and the values are presented in Table 3. In general, as expected, potentials derivable corresponds to the wastes generated which depends on the type and number of animals slaughtered per day. As can be seen in the data, wastes contributed by sheep and goats were each less than $12 \%$ at Suleja, Minna and Lafia abattoirs. Only Karu site had a relatively higher contribution from sheep and goats valued at $28 \%$ of the total wastes. Estimate of the total solids and volatile materials were based on contributions from cattle wastes being the dominant sources, as well as those from sheep and goats.

Table 3. Estimates of total wastes generated, biomethane, electricity and mitigated methane emission potentials from the primary data.

\begin{tabular}{|c|c|c|c|c|c|}
\hline Item/Abattoir & Suleja & Minna & Lafia & Karu & Total \\
\hline Total no. of annual slaughter (Cattle) & 65,700 & 21,900 & 16,425 & 49,275 & 153,300 \\
\hline Total no. of annual slaughter (Sheep and Goats) & 6935 & 34,675 & 22,265 & 237,250 & 301,125 \\
\hline${ }^{32} \mathrm{TBW}-353 \mathrm{~kg} /$ animal $\left(10^{3} \mathrm{t} / \mathrm{y}\right)$ (Cattle) & 23.19 & 7.73 & 5.80 & 17.39 & \\
\hline${ }^{32} \mathrm{TBW}-28 \mathrm{~kg} / \mathrm{animal}\left(10^{3} \mathrm{t} / \mathrm{y}\right)$ (Sheep and Goats) & 0.19 & 0.97 & 0.62 & 6.64 & \\
\hline${ }^{32}$ Waste$-35 \%$ TBW $\left(10^{3} \mathrm{t} / \mathrm{y}\right)$ (Cattle) & 8.12 & 2.71 & 2.03 & 6.09 & \\
\hline${ }^{32}$ Waste- $-35 \%$ TBW $\left(10^{3} \mathrm{t} / \mathrm{y}\right)$ (Sheep and Goats) & 0.07 & 0.34 & 0.22 & 2.33 & \\
\hline Total waste $\left(10^{3} \mathrm{t} / \mathrm{y}\right)$ & 8.19 & 3.05 & 2.25 & 8.41 & 21.89 \\
\hline${ }^{33} \mathrm{DM}, 15 \%$ of total waste $\left(10^{3} \mathrm{t} / \mathrm{y}\right)$ & 1.23 & 0.46 & 0.34 & 1.26 & 3.28 \\
\hline${ }^{24} \mathrm{VS}, 96.7 \%$ of $\mathrm{DM}\left(10^{3} \mathrm{t} / \mathrm{y}\right)$ & 1.19 & 0.44 & 0.33 & 1.22 & 3.18 \\
\hline${ }^{34}$ BMP @ $700 \mathrm{~m}^{3} / \mathrm{t}$ vs. $\left(10^{3} \mathrm{~m}^{3}\right)$ & 831.08 & 309.23 & 228.20 & 854.21 & \\
\hline $75 \%$ factor BMP $\left(10^{3} \mathrm{~m}^{3}\right)$ & 623.31 & 231.92 & 171.15 & 640.66 & 1667 \\
\hline${ }^{32} \mathrm{PE} @ 3.73 \mathrm{kWh} / \mathrm{m}^{3} \mathrm{CH}_{4}(\mathrm{~kW})$ & 265.23 & 98.69 & 72.83 & 272.61 & 709.36 \\
\hline Spent slurry in $\left(10^{3} \mathrm{~m}^{3}\right)$ & 117 & 44 & 33 & 122 & \\
\hline PBF dry, $\left(10^{3} \mathrm{t} / \mathrm{y}\right)$ & 0.515 & 0.192 & 0.142 & 0.530 & 1.378 \\
\hline Vol. of slurry added daily $\left(\mathrm{m}^{3}\right)$ & 320 & 121 & 89 & 334 & \\
\hline${ }^{26}$ Digester Capacity, 14 days HRT $\left(\mathrm{m}^{3}\right)$ & 4500 & 1700 & 1250 & 4700 & \\
\hline
\end{tabular}

Suleja and Karu that are near Abuja had higher number of slaughtered animals which is likely to be attributed to higher human populations given the influx of people to Abuja. Therefore, it is expected that big cities like Lagos, Onitsha, Kano and Port-Harcourt would have very high number of animals slaughtered. Although detailed estimates of wastes generated in the proximity of the study sites are beyond the scope of this study, the idea of combining other biodegradable wastes with the wastes from the abattoirs may prove useful. Besides increasing the volume of materials for processing for the benefits of economy of scale, using a variety of substrates is known to increase biogas yields and profitability [45].

Estimation of Possible Reduction of GHG Emissions: A model for computation proposed by the IPCC with default values for the various coefficients and used by Tolera and Alemu [21] was applied to estimate the values of GHG reduction potential in terms of $\mathrm{t} \mathrm{CO}_{2}$ eq, Figure 5. The aggregate GHG reduction potential by installation of $\mathrm{AD}$ plants at the 4 sites is $30.71 \mathrm{tCO}_{2} \mathrm{eq}$. 


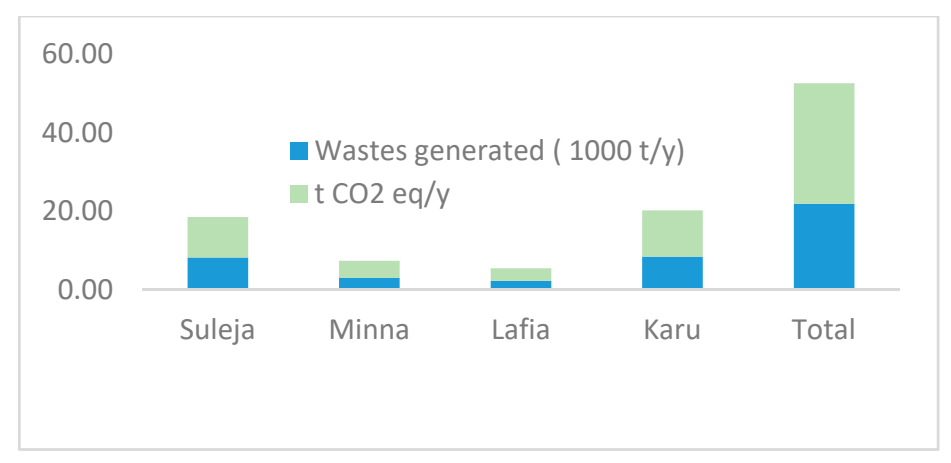

Figure 5. Annual reduction of GHGs (t $\mathrm{CO}_{2}$ eq) using anaerobic digester (AD).

Estimation of Biogas Equivalence of Fossil Fuels: The computation shows that the $1.667 \times 10^{6} \mathrm{~m}^{3} /$ year of biogas estimated is equivalent to $667 \mathrm{t}$ of furnace oil, $750 \mathrm{t}$ of liquefied petroleum gas, $834 \mathrm{t}$ of diesel, $1000 \mathrm{t}$ of kerosene, $1167 \mathrm{t}$ of petrol, and $5835 \mathrm{t}$ of charcoal/firewood per year in the same functions as presented in the Table 4.

Table 4. Estimation of equivalence of biogas potentials with some fossil fuels in the same function.

\begin{tabular}{ccccccccc}
\hline Abattoir & Waste & BMP & FO 0.4 kg & LPG 0.45 kg & D 0.5 kg & K 0.6 kg & P 0.7 kg & FW 3.5 kg \\
\hline & $\left(10^{3} \mathrm{t} / \mathrm{y}\right)$ & $\left(10^{3} \mathbf{m}^{3}\right)$ & & & $\mathrm{t}$ & & & \\
\hline Suleja & 8.19 & 623 & 249 & 280 & 312 & 374 & 436 \\
Minna & 3.05 & 232 & 93 & 104 & 116 & 139 & 162 & 2182 \\
Lafia & 2.25 & 171 & 69 & 77 & 86 & 103 & 120 & 512 \\
Karu & 8.41 & 640 & 256 & 288 & 320 & 384 & 448 & 2242 \\
Aggregate & 21.89 & 1667 & 667 & 750 & 834 & 1000 & 1167 & 5835 \\
\hline
\end{tabular}

BMB is biomethane potentials, FO is furnace oil, LPG is liquefied petroleum gas, D is diesel, $\mathrm{K}$ is kerosene, $\mathrm{P}$ is petrol, and FW is firewood.

\subsection{SWOT Assessment and Analyses}

In general, the quantitative data and qualitative description of the state of the abattoirs evaluated as presented in Sections 3.1 and 3.2 supports the SWOT factors. A concise presentation of findings from assessment and analyses of the identified SWOT factors are given below (Tables 5-8) and further discussed in the Section 4 using the results of our findings and relevant literatures.

Table 5. SWOT factors-Strengths.

\begin{tabular}{|c|c|}
\hline Identified Factor & Assessment/Finding \\
\hline Feedstock availability & $\begin{array}{l}\text { Karu abattoir had the highest feedstock value ( } 8400 \mathrm{t} / \mathrm{y}) \text {, followed closely by } \\
\text { Suleja }(8200 \mathrm{t} / \mathrm{y}) \text {, while the abattoirs at Minna and Lafia had lower values } \\
\text { ( } 3000 \text { and } 2200 \mathrm{t} / \mathrm{y} \text {, respectively). The corresponding digester capacities based } \\
\text { on optimal } 15 \% \text { total solids were } 4500,1700,1250 \text {, and } 4700 \mathrm{~m}^{3} \text {. The total } \\
\text { available feedstock which could be used for production of biogas and } \\
\text { biofertilizer for all the study sites amounts to } 21,900 \mathrm{t} / \mathrm{y} \text {. }\end{array}$ \\
\hline Suitable climate & $\begin{array}{l}\text { The region, i.e., study sites have characteristic optimum climatic condition for } \\
\text { suitable anaerobic digestion processes. Operating temperature for AD range } \\
\text { between } 10 \text { and } 55^{\circ} \mathrm{C} \text {, with } 35 \text { and } 55^{\circ} \mathrm{C} \text { being optimal for mesophilic and } \\
\text { thermophilic digestion respectively [46]. Nigeria has a tropical climate with } \\
\text { temperature ranges between } 27-40^{\circ} \mathrm{C} \text {, suitable for the optimal performance } \\
\text { of the digester, with no requirements to use the produced gas for heating the } \\
\text { reactor, unlike in Europe [47]. }\end{array}$ \\
\hline
\end{tabular}


Table 5. Cont.

\begin{tabular}{|c|c|}
\hline Identified Factor & Assessment/Finding \\
\hline $\begin{array}{l}\text { Combined provision of } \\
\text { better alternative energy } \\
\text { and biofertilizer }\end{array}$ & $\begin{array}{l}\text { Capable of generating a combined total of } 710 \mathrm{~kW} \text {. The electricity generation } \\
\text { potentials for Karu, Suleja, Minna, and Lafia abattoirs were found to be } 273 \text {, } \\
265,99 \text {, and } 73 \mathrm{~kW} \text { capacities, respectively. At the current average rate of } 13.5 \\
\mathrm{~kg} \text { fertilizer per hectare in Nigeria, the } 4 \text { study sites have a combined potential } \\
\text { to provide fertilizer for about } 100 \text { hectares. }\end{array}$ \\
\hline $\begin{array}{l}\text { Kills pathogenic } \\
\text { organisms }\end{array}$ & $\begin{array}{l}\text { It has been demonstrated that a number of pathogenic organisms like } S \text {. } \\
\text { enterica and } M \text {. paratuberculosis are reduced and inactivated in anaerobic } \\
\text { environments }[48,49] \text {. }\end{array}$ \\
\hline $\begin{array}{l}\text { Contributes in solving } \\
\text { waste disposal problems }\end{array}$ & $\begin{array}{l}\text { In all the abattoirs, the waste streams exist as a nuisance and managing them } \\
\text { is a key challenge. The wastes could therefore be dedicated to AD in a way } \\
\text { that takes care of interest groups. Harnessing these wastes as resources for } \\
\text { production of biogas for energy and biofertilizer for improved soil fertility } \\
\text { could contribute to curbing the environmental menace and addressing the } \\
\text { problems of energy and food deficits in Nigeria. }\end{array}$ \\
\hline $\begin{array}{l}\text { Reduction of GHG } \\
\text { emission and useful for } \\
\text { closing carbon cycle }\end{array}$ & $\begin{array}{l}\text { Contributes to reducing GHG emissions emanating from direct disposal to the } \\
\text { fields. Installation of ADs at the } 4 \text { sites depicts GHG reduction potential of } 30 \\
\mathrm{t} \mathrm{CO}_{2} \text { eq. }\end{array}$ \\
\hline $\begin{array}{l}\text { Existing market for } \\
\text { products }\end{array}$ & $\begin{array}{l}\text { Due to massive deforestation, there is limited forest resources and soil } \\
\text { degradation. The traditional direct use of biomass for fuel is not sustainable. } \\
\text { Moreover, there is increasing interest in more modern options such as cooking } \\
\text { gas. }\end{array}$ \\
\hline $\begin{array}{c}\text { Flexibility for small, } \\
\text { medium and large plant }\end{array}$ & $\begin{array}{l}\text { The possibility and capability to set up and run a biogas generating plant in } \\
\text { small, medium, and large scales in particular Karu and Suleja abattoirs is } \\
\text { advantageous for efficient use of resources in a sustainable and environment } \\
\text { friendly manner. Minna and Lafia sites are more suited for small and medium } \\
\text { plants to avoid the challenge of feedstock shortage. Yet, there is the benefits of } \\
\text { economy of scale in biogas plant operation where larger capacity plant is } \\
\text { more viable economically [50-52]. }\end{array}$ \\
\hline
\end{tabular}

Table 6. SWOT factors-Weaknesses.

\begin{tabular}{ll}
\hline \multicolumn{1}{c}{ Identified Factor } & Assessment/Finding \\
\hline High investment cost & $\begin{array}{l}\text { Chukwuma et al. [51] demonstrated higher value of profitability index for } \\
\text { AD plant with bigger capacity. The cost of investment for AD plant is } \\
\text { relatively high, several millions of Naira [51]. When built as small scales, such } \\
\text { as petite backyard operations, biogas systems tend to be too costly, are hardly } \\
\text { profitable, and rarely make significant contribution to the family or }\end{array}$ \\
& community [50,52]. \\
\hline $\begin{array}{l}\text { Lack of equipment } \\
\text { fabrication facilities for } \\
\text { making the digesters and } \\
\text { accessories }\end{array}$ & $\begin{array}{l}\text { There are no refabricated digesters. For diverse applications ranging from } \\
\text { cooking to electricity generation, there is need to have compatible equipment } \\
\text { and accessories such as gas holder, gas bottles, pressure regulator, water trap, } \\
\text { burner stove and lamp, biogas generating sets and biogas stoves and their } \\
\text { accessories as well as installation materials, user training and after sales } \\
\text { services. Unfortunately, these are lacking in Nigeria. }\end{array}$ \\
\hline $\begin{array}{l}\text { Lack of continuity in } \\
\text { proficiency }\end{array}$ & $\begin{array}{l}\text { No strategic, sustained, and substantial research, development, and training } \\
\text { on building robust technological capacity to set up and run such plants } \\
\text { efficiently. No technical standards and codes for AD installation and } \\
\text { maintenance and no established testing methodologies. }\end{array}$
\end{tabular}


Table 6. Cont.

\begin{tabular}{ll}
\hline \multicolumn{1}{c}{ Identified Factor } & Assessment/Finding \\
\hline $\begin{array}{l}\text { Relative novelty, } \\
\text { adoption may face } \\
\text { dislikes, sensitization } \\
\text { needed }\end{array}$ & $\begin{array}{l}\text { Adopting, adapting, and advancing a new technology often requires proper } \\
\text { sensitization, reorientation, and commitment from all stakeholders. } \\
\text { Demonstration of the technology through pilot programs and marketing may } \\
\text { be necessary in case there is the initial reluctance in adopting and adapting to } \\
\text { new techniques and products like these. }\end{array}$ \\
\hline Limited of access to water & $\begin{array}{l}\text { In all the study sites evaluated, tap water was available only at Karu site but } \\
\text { regular water flow is usually interrupted by incessant power outage. This } \\
\text { inadequate water supply has been noted as one of the challenges grabbled } \\
\text { with by the abattoirs and the neighboring residents. }\end{array}$ \\
\hline $\begin{array}{l}\text { High protein in abattoir } \\
\text { wastes }\end{array}$ & $\begin{array}{l}\text { The blood and meat trimmings are part of wastes which contribute to high } \\
\text { protein content of the wastes. }\end{array}$ \\
\hline $\begin{array}{l}\text { Pathogens from } \\
\text { contaminated materials }\end{array}$ & $\begin{array}{l}\text { Pathogens are present in the waste and can also arise from production } \\
\text { processes [53], posing hazards while handling waste inputs to the digester. }\end{array}$ \\
$\begin{array}{l}\text { Spent substrates such as biofertilizer could also contain pathogens depending } \\
\text { on the incidence of viable pathogenic organisms. in the input and spent } \\
\text { substrates. }\end{array}$ \\
\hline $\begin{array}{l}\text { Oversimplification of the } \\
\text { biogas system }\end{array}$ & $\begin{array}{l}\text { Considering it simply as a receptacle for wastes and a provider of gas and } \\
\text { fertilizer may likely cause such failures, eventually resulting in deficient } \\
\text { performance, leading to abandonment of the plant. }\end{array}$ \\
\hline
\end{tabular}

Table 7. SWOT factors-Opportunities.

\begin{tabular}{cl}
\hline \multicolumn{1}{c}{ Identified Factor } & \multicolumn{1}{c}{ Assessment/Finding } \\
\hline $\begin{array}{c}\text { Energy deficits and rural } \\
\text { settings, favors } \\
\text { decentralization }\end{array}$ & $\begin{array}{l}\text { Frequent power nationwide and most rural settings do not have access to } \\
\text { electricity and conventional cooking facilities such as LPG (cooking gas), } \\
\text { kerosene, and electricity. }\end{array}$ \\
\hline $\begin{array}{c}\text { Food insecurity and calls } \\
\text { for diversifying Nigeria's } \\
\text { economy }\end{array}$ & $\begin{array}{l}\text { Biofertilizer availability could contribute to providing a sustainable solution } \\
\text { to the current food insecurity in Nigeria. Crop yields higher by 11-20\% } \\
\text { compared to controls have been reported after the application of spent } \\
\text { digester effluent [54]. }\end{array}$ \\
\hline Improved public health & $\begin{array}{l}\text { Some aerobic organisms are killed by the fermentation process in an anaerobic } \\
\text { environment. Biogas systems could also serve as a better alternative for } \\
\text { management of abattoir waste, which could otherwise be disposed in open } \\
\text { fields forming breeding grounds for pathogenic organisms, therefore } \\
\text { enhancing public health. }\end{array}$ \\
\hline Job opportunities & $\begin{array}{l}\text { Going by Arnott's [52] projection, job opportunities for about 790 people } \\
\text { could be generated from AD plants producing a total of 1390 t of dry } \\
\text { biofertilizers at the four study sites. }\end{array}$ \\
\hline $\begin{array}{c}\text { Increased economic } \\
\text { activities }\end{array}$ & $\begin{array}{l}\text { The time spent for collecting and carrying wood by women and children } \\
\text { could be swapped for education, more productive activities, or simply } \\
\text { recreation and leisure time [55]. }\end{array}$ \\
\hline $\begin{array}{c}\text { Pynergizes global goals of } \\
\text { climate mitigation }\end{array}$ & $\begin{array}{l}\text { Estimates by this study shows the aggregate GHG reduction potential by } \\
\text { installation of AD plants at the 4 sites is 30.71 t CO } 2 \text { eq. Thus, installation of } \\
\text { AD systems could contribute in GHG mitigation by preventing disposal to the } \\
\text { open fields. The use of biogas in place of fossil-based alternatives further } \\
\text { provides avenues for reduction of GHG emissions. }\end{array}$ \\
\hline $\begin{array}{l}\text { Gaining public support might be easy owing to the socio-economic benefits } \\
\text { associated with AD systems. }\end{array}$ \\
\hline
\end{tabular}


Table 8. SWOT factors-Threats.

\begin{tabular}{cl}
\hline Identified Factor & \multicolumn{1}{c}{ Assessment/Finding } \\
\hline High lending/loan rat & $\begin{array}{l}\text { Bank lending rates in Nigeria range from 16.91\% to 29.26\% and include } \\
\text { stringent collateral requirements. This financial predicament may not be } \\
\text { favorable for investing in AD, making it difficult for willing investors to } \\
\text { start such a project despite its prospects. }\end{array}$ \\
\hline $\begin{array}{c}\text { Public subsidies for } \\
\text { fossil-based energy and } \\
\text { fertilizer }\end{array}$ & $\begin{array}{l}\text { In Nigeria, there are public subsidies for fossil-based energy and chemical } \\
\text { fertilizers. This is a threat to the competitiveness of the AD system. }\end{array}$ \\
\hline
\end{tabular}

\section{Discussion}

\subsection{Site Specific Conditions and Effects on Products}

For all the sites investigated, wastes from cattle had the largest proportion contributing $99 \%$, $89 \%, 90 \%, 72 \%$ of the total wastes corresponding to Suleja, Minna, Lafia, and Karu sites respectively. Although wastes are largely from cattle in all the sites, differences in waste composition due to contributions from varieties of the animals may influence the chemistry of the digestion processes and final products. Greater impact due to the differences could be expected from the Karu site which had the largest contribution from sheep and goats by a value of $28 \%$.

In the following sections, quantitative and qualitative data acquired from the case study are incorporated into the SWOT analysis to provide insights regarding the possibility of biogas and biofertilizer production from abattoir wastes in Nigeria.

\subsection{Strengths}

\subsubsection{Feedstock Availability}

A vital component of AD is the feedstock, which is readily available in the evaluated abattoirs. In all the abattoirs, the waste streams exist as a nuisance, and therefore, could be dedicated to AD following business agreement with the authorities and other interest groups. It is important to secure official access and also sort out any tax or fees that may be needed to afford uninterrupted access to the wastes and, as well, gain the logistic support of those concerned. The ministry of agriculture in each state is the authority in charge. Karu abattoir had the highest feedstock value (8400 $\mathrm{t} / \mathrm{y})$, followed closely by Suleja ( $8200 \mathrm{t} / \mathrm{y}$ ), while the abattoirs at Minna and Lafia had lower values (3000 and $2200 \mathrm{t} / \mathrm{y}$, respectively). The corresponding digester capacities based on optimal 15\% total solids were 4500,1700 , 1250 , and $4700 \mathrm{~m}^{3}$ corresponding to $265,99,73-$ and $273-\mathrm{kW}$ capacity in terms of electricity potentials for Suleja, Minna, Lafia and Karu abattoirs, respectively. The specific investment cost per kW or MW capacity is higher for smaller plants and lower for bigger plants [56], and this favors investment in Karu and Suleja abattoirs, where higher values of wastes are obtained compared to Lafia and Minna. Although digester capacities between $20-60 \mathrm{~m}^{3}$ are deemed good enough for small-to-medium scale business enterprises going by the assertion that a family would consume a minimum of $0.8 \mathrm{~m}^{3} / \mathrm{d}[52,57]$, thus, each of the evaluated abattoirs meets the required waste volumes to operate as medium-scale business enterprises. However, Carlini et al. [50], demonstrated an economy of scale in AD plants businesses where a larger (1000 kW capacity) plant yielded break-point in 4 years' time compared to smaller $(100 \mathrm{~kW})$ plant that took 10 years to reach break-point. Similarly, in a study of the economic viability of $\mathrm{AD}$ in 3 selected sites in Anambra state-Nigeria, Chukwuma et al. [51] demonstrated higher value of profitability index for AD plant with bigger capacity. When built as small backyard operations, biogas systems tend to be too costly, are hardly profitable, and rarely make significant contribution to the family or community [52]. The bulk of the abattoir wastes (in slurry form) is water, with just $15 \%$ TS content [24]. In view of this, decentralization of biogas plants to localities generating the biomass has more advantages than hauling the biomass to a central location [56]. Thus, there is no 
need to transport waste from one abattoir to another. However, in view of the benefit of economy of scale, possibilities of increasing the economic viability of the system could be explored by sourcing feedstock from nearby sources, like fruits and vegetable markets, animal holding places, and livestock farms e.g., poultry, piggery.

\subsubsection{Better Alternative Energy Source}

Compared to the current biomass, which is inefficiently burnt for cooking by over $81 \%$ of Nigerians dwelling in rural areas, biogas is a better source of energy. At the global level, about three billion people use biomass for cooking and heating. The biomass is burnt in inefficient cook stoves or used to fuel open fires [58]. Annually, over 4.3 million premature deaths are caused by illnesses attributable to household air pollution resulting from this practice [58]. The data of the four study sites indicate that a total of $1.667 \times 10^{6} \mathrm{~m}^{3}$ of $\mathrm{CH}_{4}$ could be generated annually as a clean source of energy. If it's used for electricity generation, it will provide a total of $709 \mathrm{~kW}(6220 \mathrm{MWh} / \mathrm{y})$. A family could consume a minimum of $0.8 \mathrm{~m}^{3} / \mathrm{d}$ of biogas for cooking [57], therefore, if the generated $\mathrm{CH}_{4}$ is used as cooking gas, it could provide for 5709 families at the rate of $0.8 \mathrm{~m}^{3} / \mathrm{d}$ per family. Thus, there is immense potential in the use of biogas from abattoir wastes which could contribute to averting the public health burden attributable to inefficient use of biomass that causes household air pollution. At household level, the accessories commonly used in places like India and Nepal where biogas is widely utilized include gas holder, gas bottles, pressure regulator, water trap, burner stove and lamp. However, these are not available in Nigeria since wide application of the technology is yet to pick-up. With a good supporting national program, such accessories and pre-fabricated digesters should be part of the tools for successful dissemination and uptake of the technology.

\subsubsection{Ability to Kill Pathogenic Organisms}

Improper organic waste disposal could provide breeding grounds for disease-causing organisms like Salmonella sp., E. coli, and Shigella sp., therefore, proper disposal is advantageous as it improves public health. Many of these pathogenic organisms are aerobic in nature and are killed by the fermentation process in an anaerobic environment. It has been demonstrated that a number of pathogenic organisms like S. enterica and M. paratuberculosis are reduced and inactivated in anaerobic environments $[48,49]$. However, AD cannot remove all the pathogens; hence biogas plants in Sweden that use slaughterhouse waste are required by law to pasteurize their substrate prior to feeding it into the digester [27]. Although desirable, it is worth noting that pasteurization could increase the cost of production.

\subsubsection{Solution to Waste Disposal Problems}

Use of the abattoir wastes for biogas systems provides a sustainable solution to the problem of waste disposal [59]. Thus, rather than spending money for waste disposal, the waste could be converted into valuable products (including biogas for energy and biofertilizer for improved soil fertility). Multiple products harvesting could improve the economy of AD operations. It is worth noting here, that treatment of digestate from biogas production can also be costly, especially if transported from far distances. Indeed, several researches have been going on in developing cost-effective processes for nutrients recovery and components separation from biogas digestate such as nutrient recovery from digestate and production of tailor-made chemicals, production of organic chemicals by treatment of effluents, etc. [60]. Separation techniques that have been explored include solid-liquid separation of digestate, using for example, membrane purification, screw press or centrifuge [60]. Nevertheless, market leading technology is still to evolve [60]. 


\subsubsection{Suitability of the Climate}

Operating temperature for $\mathrm{AD}$ range between 10 and $55^{\circ} \mathrm{C}$, with 35 and $55{ }^{\circ} \mathrm{C}$ being optimal for mesophilic and thermophilic digestion respectively [46]. Nigeria has a tropical climate with temperature ranges between $27-40{ }^{\circ} \mathrm{C}$, which is perfect for the optimal performance of the digester. Thus, the extra cost of heating the reactor could be done away with in most parts of Nigeria throughout the year, unlike temperate regions such as Europe, where $20-30 \%$ of gas production is used for heating [47]. To improve the economy of AD operation, the option of cogeneration or combined heat and power (CHP) is an appropriate method to be considered. In this method, beside electricity, the heat generated could be harnessed. This is a well-known technology widely applied in some countries in the temperate regions like the Sweden, Germany, Italy, etc. where the process heat is converted to meet household heating needs or provide for the heating needs of some operations/processes like AD. In the case of a tropical country like Nigeria, the prospects of channeling the heat for industrial drying could be the future in incorporating the concept of CHP in AD technology development.

\subsubsection{Reduction of GHG Emissions and the Use for Closing the Carbon Cycle}

AD treatment of wastes to obtain biogas prevents GHG emissions emanating from direct disposal to the fields, as well, the use of biogas as alternative to fossil-based fuels further contributes in reducing the release of GHG emissions, thus a climate smart alternative [61]. The additional environmental benefits in installing ADs are corroborated by the greenhouse gas (GHG) reduction potential, an aggregate value of 30 ton of $\mathrm{CO}_{2}$ equivalents per year for the study sites. As well, in terms of energy output, the aggregate value of $1667 \times 10^{3} \mathrm{~m}^{3}$ of biomethane potential for the study sites could substitute an average of $750 \mathrm{t}$ of fossil-based fuels (LPG, kerosene, petrol, diesel) or $5835 \mathrm{t}$ of firewood. The use of digestate can lead to enhancement of soil carbon content. The biomass used to produce biogas is indirectly derived from photosynthesis. When burnt, the released $\mathrm{CO}_{2}$ is reabsorbed in subsequent photosynthetic processes. This presents a closed carbon cycle loop, and thus presents an environment-friendly source of energy.

\subsubsection{Existing Market for Products}

The increasing population and growing wealth in Nigeria have resulted in a growing demand for both energy and biofertilizer products. Moreover, there is a deficit with regard to these two products, and therefore, they are likely to find buyers. In addition to these readily accessible market opportunities, the feed-in tariff to the national gas grid presents another prospective market outlet. When chemical fertilizer was introduced in Nigeria some farmers were reluctant in patronizing it, however it became a sought-after product when positive outcome from initial testers were revealed. Similarly, it is possible that some farmers may be reluctant to use the digestate, however, positive outcome from initial testers would likely attract more customers. It is also worth noting that the use of animal dung as source of biofertilizer is common among farmers in Nigeria especially by mixed farming practitioners, one of the widely practiced systems in Nigeria. Poultry droppings, cattle, sheep and goats' dung are already highly valued fertilizers by many farmers.

\subsection{Weaknesses}

\subsubsection{High Investment Costs}

Recently, Chukwuma et al. [51] evaluated the economic viability of biogas plant in 3 selected sites in Anambra state of Nigeria to be fed using cattle and chicken dung. Based on the estimated volumes of feedstock to be hauled to central location of each community, plant capacities of 3661.35, 3969.45- and 3546.18-kW electricity for Onitsha North, Njikoka and Dunukofia were projected respectively. The total cost of investment consisting of fixed cost and variable or annual costs (maintenance, transportation and operational cost) were 3.895, 4.155 and 3.797 billion Nigerian Naira equivalent to 10.760, 11.478 and 10.488 million USD in that order. In another study of Italian scenario aimed at analyzing the economic performance of co-digestion plants fed with agro-industrial wastes as a function of installed 
capacity in $\mathrm{kW}$, the study revealed the benefits of economy of scale in biogas plant operation where larger capacity plant is more viable economically [50]. The study revealed total investment costs of $758,000 €, 2.147$ million $€$ and 3.217 million $€$ and breakpoints of 10,5 and 4 years for plant capacities of 100, 500 and $1000 \mathrm{~kW}$ respectively [50]. Although the cost estimate for Nigeria's scenario by Chukwuma et al. [51] that indicates $2892 \mathrm{USD} / \mathrm{kW}$ for the most viable option seems on the high side, it is however cheaper compared to Italian scenario by Carlini et al. [50] which gave a value $3667 \mathrm{USD} / \mathrm{kW}$. From these examples the investment cost for medium-scale biogas systems (which could be operated profitably), as against a small backyard system (which is hardly profitable), is extremely difficult for direct investment without some funding facilities to stimulate investment. Unfortunately, investing in $\mathrm{AD}$ does not seem attractive because most people prefer investments with clear financial returns than the overall environmental and socio-economic benefits. The idea of pro-bono investment is also unfortunately not common in Nigeria. Thus, the onus lies with stakeholders in the public sector to develop programs and policies that should stimulate and facilitate investments in this sector. The public sector should embrace a national biogas program as service offerings of energy provision, water provision and recycling, waste treatment, and nutrient capture for improved food production which are valuable inputs to socio-economic development in Nigeria. Leveraging the feed-in tariff policy in Nigeria, it may be possible to raise the value of $\mathrm{AD}$ products so that they could favorably become competitive with prices of alternative products in the markets.

\subsubsection{High Protein in Abattoir Wastes}

The blood and meat trimmings in abattoir wastes are high protein content waste products [24,62]. This content could be a source of sulfide formation during the AD process. Accumulation of sulfides in the digester results in higher concentrations of corrosive hydrogen sulfide $\left(\mathrm{H}_{2} \mathrm{~S}\right)$ in the biogas, ultimately leading to sulfide inhibition of the methanogens $[63,64]$. In addition to sulfide formation due to high protein content, ammonia is formed when protein degrades. The presence of ammonia increases the $\mathrm{pH}$ in the digester. If the proportion of wastes from the abattoir is very high, the $\mathrm{pH}$ is likely to increase beyond 8.0 which can be growth-limiting for some volatile fatty acid (VFA)-consuming methanogens [65]. At such high $\mathrm{pH}$ values, the high fermentation rates of proteins and fats are accompanied by fatty acid accumulation. Additionally, the presence of neutral $\mathrm{NH}_{3}$ in the digester could be toxic to some beneficial microorganisms as $\mathrm{NH}_{3}$ can easily pass through the cell membranes of bacteria, disrupting intercellular $\mathrm{pH}$ and concentrations of other ions [64]. It is thus desirable to lower $\mathrm{NH}_{3}$ levels in the high-protein substrate materials during AD. This is an area of active research for recovery of the $\mathrm{NH}_{3}$ or providing alternative pathways to circumvent the problems [66,67]. Furthermore, at increased $\mathrm{pH}$ and temperature, the equilibrium shifts towards toxic $\mathrm{NH}_{3}$ levels, giving rise to undesired synergistic relationships among the three parameters [68]. Despite these problems, results have shown that an alternative $\mathrm{CH}_{4}$-producing pathway is activated at elevated levels of $\mathrm{NH}_{3}$ [69]. Acetate is converted into $\mathrm{H}_{2}$ and $\mathrm{CO}_{2}$ in this pathway by syntrophic acetate oxidizers (SAOs), followed by the subsequent reduction of $\mathrm{CO}_{2}$ to $\mathrm{CH}_{4}$ by hydrogen-utilizing methanogens. Thus, through this pathway, methane is produced by selective inhibition of acetate-utilizing methanogens, as $\mathrm{NH}_{3}$ released during protein degradation [69]. The potentially low $\mathrm{C} / \mathrm{N}$ ratio of slaughterhouse waste can be improved by co-digestion with some other feedstock such as manure, sewage sludge, food waste or straw [34]. Generally, co-digestion with other substrates help by diluting the toxic components, improving $\mathrm{C} / \mathrm{N}$ ratio and imparting $\mathrm{pH}$ and moisture content adjustments [70,71].

\subsubsection{Pathogens from Contaminated Materials}

Pathogens are present in the waste and can also arise from production processes [53], posing hazards while handling waste inputs to the digester. Spent substrates such as biofertilizer could also contain pathogens depending on the incidence of viable pathogenic organisms in the input and spent substrates. The survival rate of these organisms in the sludge could determine the need for additional treatment of the spent substrates. While precautionary measures may be needed in handling 
the wastes, laboratory analysis to test for the presence of pathogenic organisms and ensure process quality control in the input and output substrates is necessary. Alternative solution to this problem is to pasteurize the feedstock before $\mathrm{AD}$ treatment as done in Sweden and probably some other countries.

\subsubsection{Lack of Continuity in Developing Technical Proficiency}

Long term success in operating an $\mathrm{AD}$ system requires continuity on research and development-making observations on the go and resolving problems, and policy creation and implementation regarding hygiene and environmental standards. These are lacking in Nigeria, for example, there are no technical standards and codes for AD installation and maintenance and no established testing methodologies. Contributing to these weaknesses is that public institutions and the legal system are often unable to monitor and enforce the law over the long term [72]. A government administration that could ensure sanity by enforcing rule of law could support AD to thrive.

\subsubsection{Relative Novelty}

Adapting to a new technology generally requires sensitization, reorientation, and commitment from all stakeholders. In some cases, demonstration of the technology through pilot programs and marketing could solve the initial reluctance in adopting and adapting to new techniques. Such adaptation necessitates the establishment and implementation of awareness programs, which entail an additional cost, like releasing a new product in the market. One circumstance that favors adopting and adapting to AD systems is the decreasing forest resources in which in some cases people travel several kilometers to hunt for wood fuel. AD system would therefore present an amenable alternative that could lift off the burden of the hardship faced in scouting for wood fuel plus the negative impacts on health and environment in its use.

\subsubsection{Limited Access to Water}

Water availability is one of the conditions that could potentially limit the uptake of AD. In all the study sites evaluated, tap water was available only at Karu site but regular water flow is usually interrupted by incessant power outage. This is a depiction of most situations of dilapidated social amenity infrastructure in Nigeria that need to be addressed to become more investment friendly. Under normal conditions, the public sector provides such facilities while firms like AD company only need to pay utility bills. Although each of the study site is situated at municipal areas, with pipe borne water supply from existing rivers or dams, the water supply is, however, inconsistent. For example, the nearest dam to Karu is Usman Dam that supply Abuja municipal areas including Karu. The inconsistency in water supply may be due to power failure, poor maintenance and poor budget administration of funds allocated for the purpose.

\subsubsection{Oversimplification of the Biogas System}

A sizable number of AD pilot plants in Nigeria have failed to deliver the desired goals in the past. The goals of the pilot plant are to demonstrate the process, learn from its working and move to the stage of application. Oversimplification of the biogas system by considering it simply as a receptacle for wastes and a provider of gas and fertilizer was likely the cause for such failures, as it eventually resulted in deficient performance, leading to abandonment of the technology. Most of the biogas plants established in the past were pilot-scale demonstrations using public funds, lacking the required follow-up to make it work. For the system to work, there is need for both the contractors (suppliers) and beneficiaries to work together with a mindset of providing solution. For example, following instructions, feedback, record keeping, keenly making observations, fixing problems, trying options etc. are necessary in ensuring that a system works, giving room for further improvement. In case of any pilot demonstration plants, beneficiaries should be made to have some stakes for better ownership and commitment. Private sector investment could contribute to resolving this threat. 


\subsection{Opportunities}

\subsubsection{Energy Deficits and Rural Settings Favor Decentralization}

About $70 \%$ of Nigerians dwell in rural areas, working as peasant farmers. They have limited access to modern cooking facilities such as LPG (cooking gas), kerosene, and electricity. Moreover, only about $36 \%$ of Nigerians have access to electricity and power outages are common. These factors favor decentralization of biogas and fertilizer production in communities where feedstocks are more readily available, as well, the products generated from $\mathrm{AD}$ can be used by the community.

\subsubsection{Food Insecurity and Calls for Diversifying Nigeria's Economy}

At the current average rate of $13.5 \mathrm{~kg}$ fertilizer per hectare in Nigeria, the 4 study sites have a combined potential to provide fertilizer for about 100 hectares. Biofertilizer availability could contribute to providing a sustainable solution to the current food insecurity in Nigeria. Crop yields higher by $11-20 \%$ compared to controls have been reported after the application of spent digester effluent [54]. In the same vein, the application of spent digester effluent has healing effects on soil structure, countering the detrimental influence of increasing soil acidity, topsoil erosion, and micro-nutrient depletion due to long-term usage of inorganic fertilizer [73]. On the other hand, despite the huge agricultural potential, Nigeria's economy largely depends on oil. Therefore, there have been several calls for diversification of Nigeria's economy. Combining these two scenarios presents great opportunities for the development of biogas systems.

\subsubsection{Improved Public Health}

Prevention of organic waste disposal in open fields which could otherwise be breeding grounds for pathogenic organisms such as Salmonella sp., E. coli, and Shigella sp., by employing AD systems leads to improved public health. Some aerobic organisms are killed by the fermentation process in an anaerobic environment. Biogas systems could also serve as a better alternative for management of human excreta, therefore enhancing public health.

\subsubsection{Job Opportunities}

Biogas plant construction is labor-intensive and could therefore provide many job opportunities for business and technical managers, construction masons, plant operators for waste loading, etc. For example, engineers and technicians with skills in design and construction of biogas facilities and accessories could become actively employed in this sector were it to be functional. In countries like Germany and Sweden, biogas is an active sector providing employment for several people. In Nepal, the Biogas Support Program provides opportunities to people by systematically improving their skills via training and providing employment to at least 9000 people [55]. There are, therefore, several untapped job opportunities in this sector in Nigeria.

\subsubsection{Increased Economic Activity}

The generation of both biogas and biofertilizer will have a positive economic impact. Energy is the driver of economic activities, nearly every product and service require energy inputs. Availability of biogas as an alternative for cooking would help women and children who typically spend hours to hunt and collect wood for fuel. The time spent for collecting and carrying wood by women and children could be swapped for education, more productive activities, or simply leisure time [55].

\subsubsection{Synergies with Global Climate Change Mitigation Goals}

The dangers posed by climate change point to the urgency of creating and maintaining sustainable environment. For this reason, international and national leaders have set targets for climate change mitigation. For example, the Nigerian Government though the Electricity Regulatory Commission 
(NERC) has put in place a Feed in Tariff (FIT) policy aimed at promoting investment in renewable energy for power generation to achieve $10 \%$ of total energy mix [51]. AD system is one of the options that could contribute to these goals. Installation of $\mathrm{AD}$ systems in the various abattoirs in Nigeria could contribute in $\mathrm{CH}_{4}$ emissions mitigation by preventing disposal to the open fields. In addition to this, mitigations of other emissions like $\mathrm{CO}_{2}$ and $\mathrm{N}_{2} \mathrm{O}$ are also possible. The use of biogas in place of fossil-based alternatives further provides avenues for mitigation of GHG emissions. Significant impact could be made in mitigating GHG emissions by a national program that could widen the scope to cover the states of the federation and by sustaining efforts long into the future for cumulative effect. Investing in this sector is a step in the right direction especially as it synergizes global climate change mitigation goals.

\subsubsection{Logistic Support from the Public}

Given the socio-economic benefits associated with AD systems, securing public support is likely. For example, the top priorities for most government and development agencies include job creation, improved access to power, food security, and improving the quality of life of the citizens. These goals fit well with the benefits accruable by adopting AD technology. This could be a powerful tool in reaching out to citizens who are in desperate need for solutions to improve the quality of life. In most cases, these are some of the campaign promises that politicians make to get voted into power, therefore AD system could be a tool to deliver dividends of democracy to the citizens.

\subsection{Threats}

\subsubsection{High Lending Rate}

As the investment cost for $\mathrm{AD}$ is prohibitive, bank loans could serve as a possible funding facility. However, in Nigeria bank lending rates range from 16.91 to $29.26 \%$ and include stringent collateral requirements. This financial predicament may not be favorable for investing in $\mathrm{AD}$, making it difficult for willing investors to start such a project despite its prospects. However, since investment in this sector shares synergies with the global goals of food and energy security as well as environmental sustainability, appropriate policy planning could help to resolve this threat in favor of the technology's uptake. Higher rates of AD application experienced in China, India, Germany and Nepal are due to government supporting policies and financial incentives.

\subsubsection{Public Subsidies for Fossil-Based Energy and Fertilizers}

Public subsidies for fossil-based energy and chemical fertilizers may threaten the competitiveness of the AD system. The system does not enjoy a large public support currently, and thus, there is no level playing ground in financial terms for investing in the technology, rendering it a risky venture. Besides the subsidies, carbon emissions and soil degradation resulting from the use of conventional fossil energy sources and synthetic fertilizers respectively, are not accounted for. Thus, conventional technologies appear superior to cleaner energy options in purely financial terms [72]. Attaching a price to carbon as an incentive in the event of carbon reduction, as is the case in the Clean Development Mechanism, can help to tackle part of this problem. In a policy brief by Bassi et al. [74], it was pointed out that the EU should focus on carbon market as a better strategy than subsidies for low-carbon renewable energy to achieve further reductions in emissions from power sectors. Further, it was stated that renewable sources of electricity are becoming cost-competitive with fossil fuels and will soon no longer need subsidies [74]. Indeed, climate policy incentivizes renewable energy technologies growth more compared to conventional businesses. As of 2011, no African country has placed a price on carbon and thus there is no truly level playing field in terms of cost and benefits between conventional and renewable technologies [72]. However, in 2015, there was a dialogue on adopting carbon pricing in Lagos, Nigeria, during which the stakeholders endorsed the idea and explored essential modalities. 
The key outcome was the formation of the Carbon Pricing Leadership Coalition Nigeria [75]. Therefore, this threat can be tackled by keying into global carbon markets.

\section{Conclusions}

In this case study, a multi-criteria approach was used where quantitative data from the study sites were incorporated into the SWOT analysis to assess the prospects of AD systems for abattoir wastes management in Nigeria as a cleaner technology approach. The study established more strengths and opportunities than weaknesses and threats in favor of uptake of AD technology. The wastes generated in each abattoir in the study sites meets the required volume to operate as small to medium scale business enterprise. Furthermore, if AD systems are installed in the four study sites, combined potentials of about $1.66 \times 10^{6} \mathrm{~m}^{3} / \mathrm{y}, 1380 \mathrm{t} / \mathrm{y}, 709 \mathrm{~kW}$ and $30.71 \mathrm{t} \mathrm{CO}_{2}$ eq corresponding to biomethane, dry biofertilizer, electricity and GHG reduction potentials respectively, are attainable. Larger cities, such as Lagos, Kano, Kaduna, Ibadan, Enugu, Onitsha, and Port Harcourt, which record more animal slaughters, will have corresponding higher potentials. Moreover, the prospects of sourcing more feedstock near any proposed plant, such as chicken droppings, cattle dung, pig droppings etc., from nearby farmers could enable bigger capacity plants which has better economic viability than smaller plants. Despite these benefits, there are negative factors in the SWOT analysis such as high investment cost and the relative novelty of the technology (in the internal environment), as well as high lending rates and public subsidies for fossil-based energy and fertilizer (in the external environment). Thus, to make these benefits a reality, the negative factors in the SWOT analysis must be adequately addressed using political instruments and public policies. The high propensities of surmounting these negative elements are predicated on the positive factors in the SWOT analysis. The positive factors include provision of clean energy and spent slurry as biofertilizer, destruction of some pathogenic organisms, solving waste disposal problems, and existing needs for both biogas and biofertilizer (in the internal environment). Other factors in the external environment that could incentivize uptake of AD systems include persisting energy deficits and food insecurity in Nigeria, the prospects for improved public health, job opportunities, and the fact that the AD system shares synergies with global climate change mitigation goals, like mitigating GHG emissions. In general, although the study revealed much potential for investment in AD system to harness the wastes generated in Nigerian abattoirs, a lot needs to be done to tackle the hindering factors. Based on these findings, the study recommends private sector investment supported by public policies. Public support in form of national programs with the mandate of providing coordinated research and development, marketing, technical, facilitating access to climate funding opportunities, financial supports and framework as well as setting out standards, codes and regulation for the private sector participation, are required for progress.

Author Contributions: I.G.A. conceived and designed the study; I.G.A. performed the site evaluation survey; I.G.A., B.M.L., O.M.T., P.A.O. and A.B. analyzed the data; I.G.A. and A.B. wrote the paper; B.M.L., O.M.Y., P.A.O. and A.B. revised the paper critically for intellectual inputs. All authors have read and agreed to the published version of the manuscript.

Funding: This research was funded by the Raw Materials Research and Development Council, Abuja—Nigeria; we are grateful.

Acknowledgments: The authors wish to thank the Raw Materials Research and Development Council, for funding this study. The authors also thank Wolfgang Glasser and Kemjika Ajoku who read the manuscript and made useful comments. Mike Hobbs edited the manuscript for English gramma errors. We are grateful. Maria Obi also supported in some aspects of the site evaluation; we are grateful.

Conflicts of Interest: The authors declare no conflict of interest. 


\section{References}

1. IEA. International Energy Agency. France. 2019. Available online: https://www.iea.org/countries/Nigeria/ (accessed on 10 December 2019).

2. Energypedia. 2019. Available online: https://energypedia.info/wiki/Nigeria_Energy_Situation\#cite_refJICA.2C_February_2007.2C_The_Master_Plan_Study_for_Utilization_of_Solar_Energy_in_the_Federal_ Republic_of_Nigeria.2C_Final_Report.2C_Volume_1.2C_p._3-20_8-0 (accessed on 22 December 2019).

3. World Resources Institute Climate Analysis Indicators Tool (WRI CAIT 4.0, 2017). GHG Emissions are Reported in Units of Carbon Dioxide Equivalents. Global Warming Potentials (GWPs) are the 100-Year GWPs from the Intergovernmental Panel on Climate Change (IPCC) Second Assessment Report (SAR); World Resources Institute: Washington, DC, USA, 2017.

4. Knee, A. The Nature of Energy; Magazine of the World Conservation Union; International Union for Conservation of Nature and Natural Resources: Gland, Switzerland, 2007; pp. 1-44.

5. Sanusi, R.A.; Badejo, C.A.; Yusuf, B.O. Measuring household food insecurity in selected local government areas of Lagos and Ibadan, Nigeria. Pak. J. Nutr. 2006, 5, 62-67.

6. Abu, O. Food security in Nigeria and South Africa: Policies and challenges. J. Hum. Ecol. 2012, 38, 31-35. [CrossRef]

7. IPCC. Climate Change 2014: Mitigation of Climate Change, Contribution of Working Group III to the Fifth Assessment Report of the Intergovernmental Panel on Climate Change; Cambridge University Press: Cambridge, UK; New York, NY, USA, 2014.

8. Zhang, J.; Jiang, J.; Tian, G. The potential of fertilizer management for reducing nitrous oxide emissions in the cleaner production of bamboo in China. J. Clean. Prod. 2016, 112, 2536-2544. [CrossRef]

9. Adeyemi, I.G.; Adeyemo, O.K. Waste management practices at the Bodija abattoir, Nigeria. Int. J. Environ. Stud. 2007, 64, 71-82. [CrossRef]

10. Adeyemo, O.K.; Adeyemi, I.G.; Awosanya, E.J. Cattle cruelty and risks of meat contamination at Akinyele cattle market and slaughter slab in Oyo State, Nigeria. Trop. Anim. Heal. Prod. 2009, 41, 1715-1721. [CrossRef]

11. Chukwu, O.; Adeoye, P.A.; Chidiebere, I. Abattoir Waste Generation, Management and the Environment: Minna, Nigeria. Int. J. Biosci. 2011, 1, 100-109.

12. Oruonye, E.D. Challenges of Abattoir Waste Management in Jalingo Metropolis, Nigeria. Int. J. Resour. Geogr. 2015, 1, 22-23.

13. Salminen, E.; Rintala, J. Anaerobic digestion of organic solid poultry slaughterhouse waste-A review. Bioresour. Technol. 2002, 83, 13-26. [CrossRef]

14. Akinbami, J.-F.; Ilori, M.; Oyebisi, T.; Akinwumi, I.; Adeoti, O. Biogas energy use in Nigeria: Current status, future prospects and policy implications. Renew. Sustain. Energy Rev. 2001, 5, 97-112. [CrossRef]

15. Lukehurst, C.T.; Frost, P.; Seadi, T.A. Utilization of digestate from biogas plants and biofertilizer, task 37. IEA Bioenergy 2010, 24.

16. Amon, T.; Bredow, H.V.; Gromke, J.D.; Dohle, H.; Fischer, E.; Fischer, E.; Friehe, J.; Gattermann, H.; Grebe, S.; Grope, J.; et al. Guide to Biogas-from Production to Use; Fachagentur Nachwachsende Rohstoffe e. V. (FNR): Eschborn, Germany, 2010.

17. Cvetkovic, S.; Radoičić, T.K.; Vukadinović, B.; Kijevčanin, M.L. Potentials and status of biogas as energy source in the Republic of Serbia. Renew. Sustain. Energy Rev. 2014, 31, 407-416. [CrossRef]

18. Amigun, B.; Von Blottnitz, H. Capacity-cost and location-cost analyses for biogas plants in Africa. Resour. Conserv. Recycl. 2010, 55, 63-73. [CrossRef]

19. IPCC/Intergovernmental Panel on Climate Change, National Greenhouse Gas Inventories and Uncertainty Management in National Greenhouse Gas Inventories, IPCC National Greenhouse Gas Inventory Program. 2000. Available online: http://www.ipcc-nggip.iges.or.jp/public/gp/gpgaum.htm. (accessed on 28 March 2019).

20. JGCRI/Joint Global Change Research Institute, GCAM v4.4 Documentation: Global Change Assessment Model (GCAM), Documentation for GCAM. 2018. Available online: http://jgcri.github.io/gcam-doc/. (accessed on 27 February 2019).

21. Tolera, S.T.; Alemu, F.K. Potential of Abattoir Waste for Bioenergy as Sustainable Management, Eastern Ethiopia, 2019. J. Energy 2020, 2020, 6761328. [CrossRef] 
22. Kholif, A.; Elghandour, M.M.M.Y.; Rodríguez, G.; Olafadehan, O.; Salem, A.Z.M. Anaerobic ensiling of raw agricultural waste with a fibrolytic enzyme cocktail as a cleaner and sustainable biological product. J. Clean. Prod. 2017, 142, 2649-2655. [CrossRef]

23. Klintenberg, P.; Jamieson, M.; Kinyaga, V.; Odlare, M. Assessing Biogas Potential of Slaughter Waste: Can Biogas Production Solve a Serious Waste Problem at Abattoirs? Energy Procedia 2014, 61, 2600-2603. [CrossRef]

24. Ware, A.; Power, N. Biogas from cattle slaughterhouse waste: Energy recovery towards an energy self-sufficient industry in Ireland. Renew. Energy 2016, 97, 541-549. [CrossRef]

25. Adamu, A.A.; Mohammed-Dabo, I.A.; Hamza, A.; Ado, S.A. Predicting rate of biogas production from abattoir waste using empirical models. Int. J. Sci. Eng. Res. 2017, 8, 1238-1245.

26. Rabah, A.B.; Baki, A.S.; Hassan, L.G.; Musa, M.; Ibrahim, A.D. Production of biogas using abattoir waste at different retention time. Sci. World J. 2010, 5, 23-26.

27. Ek, A.E.W.; Hallin, S.; Vallin, L.; Schnürer, A.; Karlsson, M. Slaughterhouse waste co-digestion-Experiences from 15 years of full-scale operation. World renewable energy congress 2011-Sweden. Bioenergy Technol. 2011, 9, 64-71.

28. Hellman, J.; Ek, A.E.W.; Sundberg, C.; Johansson, M.; Svensson, B.H.; Karlsson, M. Mechanisms of increased methane production through re-circulation of magnetic biomass carriers in an experimental continuously stirred tank reactor. In Proceedings of the 12th World Congress on Anaerobic Digestion, Guadalajara, Mexico, 31 October-4 November 2010.

29. Ngumah, C.; Ogbulie, J.N.; Orji, J.C.; Amadi, E.S. Biogas potential of organic waste in Nigeria. J. Urban Environ. Eng. 2013, 7, 110-116. [CrossRef]

30. Kurttila, M.; Pesonen, M.; Kangas, J.; Kajanus, M. Utilizing the analytic hierarchy process (AHP) in SWOT analysis-A hybrid method and its application to a forest-certification case. Policy Econ. 2000, 1, 41-52. [CrossRef]

31. Okello, C.; Pindozzi, S.; Faugno, S.; Boccia, L. Appraising Bioenergy Alternatives in Uganda Using Strengths, Weaknesses, Opportunities and Threats (SWOT)-Analytical Hierarchy Process (AHP) and a Desirability Functions Approach. Energies 2014, 7, 1171-1192. [CrossRef]

32. Akinbomi, J.; Brandberg, T.; Sanni, S.A.; Taherzadeh, M.J. Development and dissemination strategies for accelerating biogas production in Nigeria. Bioresources 2014, 9, 5707-5737.

33. Deublein, D.; Steinhauser, A. Biogas from Waste and Renewable Resources; Wiley-VCH Verlag GmbH \& Co. KGaA: Hoboken, NJ, USA, 2008; pp. 27-83.

34. Schnurer, A.; Jarvis, A. Microbiological Handbook for Biogas Plants, 1-74. Swedish Waste Management U2009:03. Swed. Gas Cent. Rep. 2010, 207, 1-74.

35. Burke, D. Dairy Waste Anaerobic Digestion Handbook; Environmental Energy Company: Olympia, WA, USA, 2001; pp. 1-57.

36. Schirmer, W.N.; Jucá, J.F.T.; Schuler, A.R.P.; Holanda, S.; Jesus, L.L. Methane production in anaerobic digestion of organic waste from Recife (Brazil) landfill: Evaluation in refuse of diferent ages. Braz. J. Chem. Eng. 2014, 31, 373-384. [CrossRef]

37. Chen, Y.R. Engineering Properties of Beef-Cattle Manure; ASAE paper no. 82-4085; ASAE: Lisbon, Portugal, 1982.

38. B-Sustain, Environmental and Social Benefits of Biogas Technology. 2013. Available online: http://www. bsustain.in/faqs.html (accessed on 22 May 2018).

39. Dzene, I.; Romagnoli, F. Comparison of different biogas use pathways for Latvia: Biogas use in CHP vs. biogas upgrading. In In Proceedings of the 9th International Conference Environmental Engineering 2014, Vilnius, Lithuania, 22-23 May 2014.

40. Kolios, A.; Read, G. A Political, Economic, Social, Technology, Legal and Environmental (PESTLE) Approach for Risk Identification of the Tidal Industry in the United Kingdom. Energies 2013, 6, 5023-5045. [CrossRef]

41. Jadidi, O.; Hong, T.S.; Firouzi, F.; Yusuff, R.M. An optimal grey based approach based on TOPSIS concepts for supplier selection problem. Int. J. Manag. Sci. Eng. Manag. 2009, 4, 104-117. [CrossRef]

42. Wind, Y.; Saaty, T.L. Marketing Applications of the Analytic Hierarchy Process. Manag. Sci. 1980, 26, 641-658. [CrossRef]

43. Liu, T.; McConkey, B.G.; Ma, Z.; Liu, Z.; Li, X.; Cheng, L. Strengths, Weaknessness, Opportunities and Threats Analysis of Bioenergy Production on Marginal Land. Energy Procedia 2011, 5, 2378-2386. [CrossRef] 
44. Kretschmer, W.; Bischoff, S.; Hanebaeck, G.; Muller, H. SWOT Analysis and Biomass Competition Analysis for SUPRABIO Biorefineries; IUS Institute for Environmental Studies, Weibel and Ness GmbH: Heidelberg, Germany, 2014.

45. Eze, J.I. Studies on Generation of Biogas from Poultry Droppings and Rice Husk from a Locally Fabricated Biodigester. Master's Thesis, University of Nigeria, Nsukka, Nigeria, 1995; pp. 64-65.

46. Connaughton, S.; Collins, G.; O'Flaherty, V. Psychrophilic and mesophilic anaerobic digestion of brewery effluent: A comparative study. Water Res. 2006, 40, 2503-2510. [CrossRef]

47. Nijaguna, B.T. Biogas Technology; Book 142 New Age International (P) Limited, Publishers 4835/24; Ansari Road: Daryaganj, New Delhi, 2006.

48. Olsen, J.E.; Larsen, H.E. Bacterial decimation times in anaerobic digestions of animal slurries. Boil. Wastes 1987, 21, 153-168. [CrossRef]

49. Kearney, T.E.; Larkin, M.; Frost, J.; Levett, P. Survival of pathogenic bacteria during mesophilic anaerobic digestion of animal waste. J. Appl. Bacteriol. 1993, 75, 215-219. [CrossRef] [PubMed]

50. Carlini, M.; Mosconi, E.M.; Castellucci, S.; Villarini, M.; Colantoni, A. An Economical Evaluation of Anaerobic Digestion Plants Fed with Organic Agro-Industrial Waste. Energies 2017, 10, 1165. [CrossRef]

51. Chukwuma, C.E.; Ndrika, V.I.O.; Chukwumuanya, E.O. Economic Viability of Bio-energy Plants for Location Analysis in Parts of Anambra State of Nigeria. JEAS 2018, 13, 40-53.

52. Arnott, M. The Biogas/Biofertilizer Business Handbook. Appropriate Technologies for Development; Peace Corps Information Collection and Exchange Manual R-48: Washington, DC, USA, 1982; pp. 1-117.

53. World Bank. Pollution Prevention and Abatement Handbook-World Bank Documents. Available online: https://www.google.de/?gfe_rd=cr\&ei=wOT_WMWpFJDVXrzyiOgE\#q=meat+processing +and+ rendering+pollution+and+prevention+abatement+handbook1998 (accessed on 10 January 2017.).

54. Marchaim, U. Biogas Processes for Sustainable Development; FAO: Rome, Italy, 1992; pp. 1-99.

55. SNV. Biogas Support Program Fuels Rural Household Energy Supply in Nepal. A Paper for UNCTAD Expert Meeting on Green and Renewable Technologies as Energy Solutions for Rural Development; SNV: Geneva, Switzerland, 2010.

56. WBA. Biogas-An Important Energy Source; Factsheets; World Bioenergy Association (WBA): Stockholm, Sweden, 2013.

57. Tumwesige, V.; Avery, L.; Austin, G.; Balana, B.; Bechtel, K.; Casson, E.; Davidson, G.; Edwards, S.; Eshete, G.; Gebreegziabher, Z.; et al. Small-Scale Biogas Digester for Sustainable Energy Production in Sub-Saharan Africa: A Review. 1st World Sustainability Forum 2011. Available online: www.wsforum.org. (accessed on 12 April 2015.).

58. WHO. Household Air Pollution and Health. Fact Sheet No. 292. Available online: http://www.who.int/ mediacentre/factsheets/fs292/en/2016 (accessed on 5 August 2017).

59. Alfa1, M.I.; Wamyil, F.B.; Daffi, R.E.; Igboro, S.B. Design, Development and Evaluation of Slaughterhouse Anaerobic Digestion Plant Model. Am. J. Eng. Res. 2017, 6, 70-74.

60. Drosg, B.; Fuchs, W.; Al Seadi, T.; Madsen, M.; Linke, B. Nutrient recovery by biogas digestate processing. IEA Bioenergy Task 2015, 37, 1-40.

61. Sindibu, T.; Solomon, S.; Ermias, D. Biogas and bio-fertilizer production potential of abattoir waste as means of sustainable waste management option in Hawassa City, southern Ethiopia. J. Appl. Sci. Environ. Manag. 2018, 22, 553. [CrossRef]

62. EC (European Commission). European Parliament Commission Regulation 2009/1069/EC. Available online: https://eur-lex.europa.eu/legal-content/en/ALL/?uri=CELEX:32009R1069 (accessed on 19 August 2020).

63. Ochieng' tieno, F.A. Anaerobic digestion of wastewaters with high strength sulfates. Discov. Innov. 1996, 8, 143-150.

64. Chen, Y.; Cheng, J.J.; Creamer, K.S. Inhibition of anaerobic digestion process: A review. Bioresour. Technol. 2008, 99, 4044-4064. [CrossRef]

65. Lay, J.-J.; Li, Y.-Y.; Noike, T. Influences of $\mathrm{pH}$ and moisture content on the methane production in high-solids sludge digestion. Water Res. 1997, 31, 1518-1524. [CrossRef]

66. Tada, C.; Yang, Y.; Hanaoka1, T.; Sonoda, A.; Ooi, K.; Sawayama, S. Effect of natural zeolite on methane production for anaerobic digestion of ammonium rich organic sludge. Bioresour. Technol. 2005, 96, 459-464. [CrossRef] [PubMed] 
67. Nordell, E.; Hallin, S.; Johansson, M.; Karlsson, M. The Diverse Response on Degradation Rate of Different Substances upon Addition of Zeolites. In Proceedings of the Third International Symposium on Energy from Biomass and Waste, Venice, Italy, 8-11 November 2010; ISBN 978-88-6265-008-3.

68. Siegrist, H.; Vogt, D.; Garcia-Heras, J.L.; Gujer, W. Mathematical Model for Meso- and Thermophilic Anaerobic Sewage Sludge Digestion. Environ. Sci. Technol. 2002, 36, 1113-1123. [CrossRef] [PubMed]

69. Schnürer, A.; Nordberg, A. Ammonia, a selective agent for methane production by syntrophic acetate oxidation at mesophilic temperature. Water Sci. Technol. 2008, 57, 735-740. [CrossRef]

70. Esposito, G.; Frunzo, L.; Liotta, F.; Panico, A.; Pirozzi, F. BMP tests to measure the biogas production from the digestion and co-digestion of Complex organic substrates. Open J. Environ. Eng. 2012, 5, 1-8. [CrossRef]

71. Patil, V.S.; Deshmukh, H.V. A review on co-digestion of vegetable waste with organic wastes for energy generation. Int. Res. J. Biol. Sci. 2015, 4, 83-86.

72. Fischer, R.; Lopez, J.; Suh, S. Barriers and drivers to renewable energy investment in Sub-Saharan Africa. J. Environ. Invest. 2011, 2, 54 .

73. Sheahan, M.; Black, R.; Jayne, T.S. Are farmers underutilizing fertilizer? Evidence from Kenya. In Proceedings of the International Association of Agricultural Economists (IAAE) Triennial Conference, Foz do Iguaçu, Brazil, 18-24 August 2012; pp. 18-24.

74. Bassi, S.; Carvalho, M.; Doda, B.; Fankhauser, S. Decarbonizing the European Union Credibly, Effectively and Acceptably; Policy brief; Grantham Research Institute on Climate Change and the Environment and the Centre for Climate Change Economics and Policy: London, UK, 2017.

75. Envir-News. Nigeria Adopts Carbon Pricing to Curb Global Emission. 2015. Available online: http: //www.environewsnigeria.com/nigeria-adopts-carbon-pricing-curb-global-emission/2015 (accessed on 24 April 2017).

(C) 2020 by the authors. Licensee MDPI, Basel, Switzerland. This article is an open access article distributed under the terms and conditions of the Creative Commons Attribution (CC BY) license (http://creativecommons.org/licenses/by/4.0/). 